\title{
REPORT ON THE OBSERVANCE OF STANDARDS AND CODES (ROSC)
}

\author{
ACCOUNTING AND AUDITING
}

CHAD

April 2014 


\section{REPORT ON THE OBSERVANCE OF STANDARDS AND CODES (ROSC) \\ Chad}

ACCOUNTING AND AUDITING

30 April 2014

\section{TABLE OF CONTENTS}

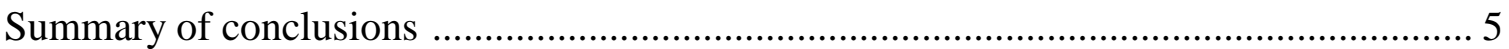

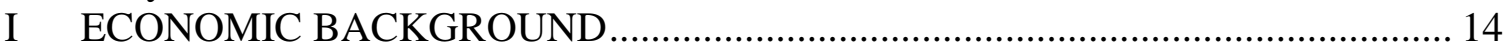

II LEGAL AND INSTITUTIONAL FRAMEWORK ………................................... 17

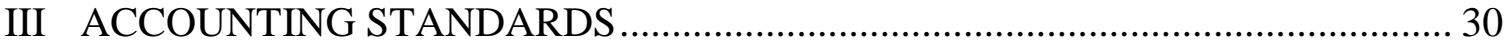

IV AUDITING STANDARDS ........................................................................... 32

$\mathrm{V}$ PERCETPTIONS REGARDING THE QUALITY OF FINANCIAL REPORTING ..... 32

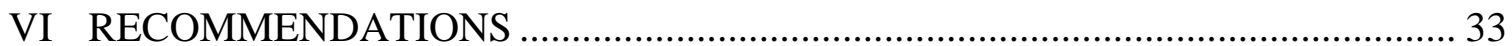

This report was drafted by a World Bank team on the basis of work carried out in Ndjamena between March and April 2013. The project team was led by Beth Mwangi (Financial Management Specialist, AFTMW, Africa Region) and thereafter by Jean Charles Kra (Senior Financial Management Specialist, AFTMW, Africa Region) and supervised by Mr Renaud Seligmann (Manager, Financial Management, AFTMW, Africa Region). Members of the team included Maîmouna Fam (Senior Financial management Specialist, AFTMW Africa region), Thierno Mbacke and Jean Paul Nendigui (Consultants), among others. The authors would like to express their gratitude to the Chadian authorities and representatives of the accountancy profession and the private sector, for their active participation and support during the study. This report was authorised for publication by the Ministry of Finance and Budget on May 21, 2014. 


\section{ACRONYMS AND ABBREVIATIONS \\ CURRENCY: FRANC CFA (FCFA or XAF) \\ EXCHANGE RATE: 1 USD = 502 FCFA AT 20 MARCH 2013}

\begin{tabular}{|c|c|c|c|}
\hline ACCA & $\begin{array}{l}\text { Association of Chartered Certified } \\
\text { Accountants }\end{array}$ & IES & $\begin{array}{l}\text { International Education Standards for } \\
\text { professional accountants }\end{array}$ \\
\hline \multirow[t]{2}{*}{ ANECAT } & $\begin{array}{l}\text { Association nationale des Experts } \\
\text { comptables et Comptables agréés du } \\
\text { Tchad }\end{array}$ & IFAC & $\begin{array}{l}\text { International Federation of } \\
\text { Accountants }\end{array}$ \\
\hline & $\begin{array}{l}\text { Tchad } \\
\text { Banque des États d'Afrique Centrale }\end{array}$ & IFRS & $\begin{array}{l}\text { International Financial Reporting } \\
\text { Standards }\end{array}$ \\
\hline CAC & Commissaire aux comptes & INTOSAI & International Organization for \\
\hline \multirow[t]{2}{*}{ CCJA } & \multirow{2}{*}{$\begin{array}{l}\text { Cour Commune de Justice et } \\
\text { d'Arbitrage }\end{array}$} & & Supreme Audit Institution \\
\hline & & ISA & International Standards on Auditing \\
\hline \multirow[t]{2}{*}{ CEMAC } & \multirow{2}{*}{$\begin{array}{l}\text { Communauté Économique et } \\
\text { Monétaire d'Afrique Centrale (Central } \\
\text { African Economic and Monetary } \\
\text { Union-CAEMU) }\end{array}$} & MIFB & Ministry of Finance and Budget \\
\hline & & OECD & $\begin{array}{l}\text { Organisation for Economic } \\
\text { Cooperation and Development }\end{array}$ \\
\hline CIMA & $\begin{array}{l}\text { Union-CAEMU) } \\
\text { Conférence Interafricaine des Marchés }\end{array}$ & OHADA & $\begin{array}{l}\text { Organisation pour l'Harmonisation en } \\
\text { Afrique du Droit des Affaires }\end{array}$ \\
\hline CNPT & $\begin{array}{l}\text { d'Assurances } \\
\text { Confédération nationale du patronat } \\
\text { tchadien }\end{array}$ & PCEC & $\begin{array}{l}\text { Plan Comptable des Établissements de } \\
\text { Crédit (Chart of accounts for credit } \\
\text { institutions) }\end{array}$ \\
\hline COBAC & $\begin{array}{l}\text { Commission Bancaire d'Afrique } \\
\text { Centrale }\end{array}$ & PCG & $\begin{array}{l}\text { Plan comptable général (General } \\
\text { accounting plan) }\end{array}$ \\
\hline \multicolumn{4}{|c|}{ COSUMAF Commission de Surveillance du } \\
\hline & $\begin{array}{l}\text { Marche Financler de l Afrique } \\
\text { Centrale }\end{array}$ & & Small and medium-sizes enterprises \\
\hline CRCA & $\begin{array}{l}\text { Commission Régionale de Contrôle des } \\
\text { Assurances }\end{array}$ & KUSC & $\begin{array}{l}\text { Report on Ubservance of Standards } \\
\text { and Codes }\end{array}$ \\
\hline DEC & $\begin{array}{l}\text { Diplôme d'Expertise Comptable } \\
\text { (Public accountancy diploma) }\end{array}$ & $\mathrm{KCC}$ & $\begin{array}{l}\text { Registre du Commerce et du crédit } \\
\text { mobilier }\end{array}$ \\
\hline DGI & $\begin{array}{l}\text { Direction Générale des Impôts } \\
\text { (General Tax Office) }\end{array}$ & EGA & $\begin{array}{l}\text { Guide on accounting and financial } \\
\text { reporting for SMEs }\end{array}$ \\
\hline DSF & Déclaration Statistique et Fiscale & SMO & $\begin{array}{l}\text { IFAC Statement of Membership } \\
\text { Obligations }\end{array}$ \\
\hline EPP & Para-state enterprise & TAFIRE & Tableau financier des ressources et \\
\hline \multirow[t]{2}{*}{ ERSUMA } & \multirow{2}{*}{$\begin{array}{l}\text { Ecole régionale supérieure de la } \\
\text { magistrature }\end{array}$} & & \\
\hline & & UA & Uniform Act \\
\hline FCFA & $\begin{array}{l}\text { Franc de la Coopération Financière en } \\
\text { Afrique Centrale }\end{array}$ & UNCTAD & $\begin{array}{l}\text { United Nations Conference on Trade } \\
\text { and Development }\end{array}$ \\
\hline FIDEF & $\begin{array}{l}\text { Fédération Internationale des Experts- } \\
\text { Comptables Francophones }\end{array}$ & UEMOA & $\begin{array}{l}\text { Union Économique et Monétaire } \\
\text { Ouest-Africaine (West African }\end{array}$ \\
\hline GDP & Gross domestic product & & Economic and Monetary Union- \\
\hline GIE & Groupement d'intérêt économique & & WAEMU) \\
\hline IAASB & $\begin{array}{l}\text { International Auditing and Assurance } \\
\text { Standards Board }\end{array}$ & UDEAC & $\begin{array}{l}\text { Union Douanière et Économique } \\
\text { d'Afrique Centrale (Central African }\end{array}$ \\
\hline \multirow[t]{2}{*}{ IAS } & \multirow{2}{*}{$\begin{array}{l}\text { Normes Internationales de } \\
\text { Comptabilité }\end{array}$} & & Customs and Economic Union) \\
\hline & & USD & US Dollar \\
\hline IASB & $\begin{array}{l}\text { International Accounting Standards } \\
\text { Board }\end{array}$ & VSE & Very small enterprise \\
\hline IASC & $\begin{array}{l}\text { International Accounting Standards } \\
\text { Committee }\end{array}$ & & \\
\hline IMF & International Monetary Fund & & \\
\hline $\mathrm{PO}$ & Public offering & & \\
\hline PRSP & Poverty reduction strategy paper & & \\
\hline
\end{tabular}




\section{Summary of Conclusions}

The auditing profession in Chad is characterised by the existence of numerous practitioners who provide accounting and auditing services illegally, in violation of community regulations, and whose qualifications often do not meet the international standards. There is currently only one Certified Public Account (of France) in Chad, with 22 CEMAC accredited accountants and about fifty people who have been accredited as public accountants by the Court of Appeal of Ndjamena, although their qualifications do not comply with any clearly predefined reference framework. It must be pointed out that of the six CEMAC member countries, only Cameroon and the Central African Republic have set up a national association of chartered accountants.

The legal and regulatory frameworks governing the accounting and auditing professions have not changed much in Chad since the OHADA accounting system was adopted as the reference for accounting standards, and since the entry into force of the CEMAC community regulations on the accountancy profession in the early 2000s. The major challenge for Chad today is to ensure that various community directives and rules are transposed into national regulations in order to give new impetus to the accountancy and auditing professions in the country. It is necessary to point out that regional directives have a major bearing on the member countries as these directives are decided and voted by all the member countries usually represented by their respective Finance Ministers.

To date, Chad has not yet set up a national association of chartered accountants. One of the most pressing areas in transposing community texts relates to the establishment of a national association of chartered accountants, whose existence is essential for the development and practice of the accountancy profession in Chad. It is also important for consolidating accounting and auditing processes, improving the quality of financial reporting, facilitating access to credit and supporting foreign direct investors, as well as improving the competitiveness of national businesses. Indeed, the establishment of the professional body is an absolute necessity if the accountancy profession is to be developed significantly in Chad. It would in particular make it possible to establish an important base for enhancing the credibility of the profession by developing initial and continued accountancy training; assisting its members in applying accounting and auditing standards and code of ethics nationally; developing quality assurance standards, and generally observing the relevant ethical principles. In an initiative guided by their awareness of these facts, accounting technicians accredited by the Court of Appeal of Ndjamena came together in 2011 to form an association known as the Association des Experts comptables et Comptables Agréés du Tchad (ANECAT). This association is however not very active. According to the CEMAC regulations governing the accountancy profession, accounting technicians are expected to be reclassified in the category of public accountants. The reclassification process is underway in various countries in the CEMAC region, Chad and Congo being among them. The CEMAC-accredited accounting technicians in these countries who have undergone the required prerequisite training will be reclassified as public accountants, in accordance with CEMAC regulations for the accounting profession. The training sessions organised in Ndjamena in 2012 in conjunction with the CEMAC and with support from the World Bank are part of the process towards this reclassification. For Chad, the reclassification of the 22 accredited accountants is a necessary prerequisite for the establishment of a national association of chartered accountants in the short term, as well as for its sustainability. The authorities must therefore support the initiative to reclassify accredited accounting technicians and promote the adoption of the draft decree establishing a national association of chartered accountants.

With regard to the accounting standards, the Uniform Act (UA) organising and harmonising accounting systems for businesses, as well as the accounting chart of accounts and the provisions put in place by the COBAC and the CIMA code, there has been very little change since their entry into force towards the end of the 1990s. This is due to shortcomings in the functioning of the regional bodies in charge of ensuring that these texts were updated in line with changes in the accounting, economic, and legal fields. However, the recent World Bank funded regional project aimed at improving the investment climate in the OHADA region and whose implementation has been entrusted to the latter's Permanent Secretariat, is aimed at revitalising the relevant community organs to enable them to: (i) adopt IFRS standards for public interest entities (listed companies, banks, insurance companies, and public companies), and (ii) update OHADA accounting laws for small and medium-sized enterprises (SMEs), to align them with international standards and best practice, taking into account the size and volume of such entities. Given that SMEs form a significant part of the private sector, a practical approach and starting point would be to refer a developing country that has established an accounting regulatory framework for SMEs. The challenges in effectively transposing and applying texts domestically will however persist if the National Association of Chartered Accountants is not established and if the National Accounting Standards Commission (Commission nationale de Normalisation Comptable) established in Chad in 2011 remains inactive. 
The quality of financial reporting in Chad needs to be improved. It is generally acknowledged that businesses publish different balance sheets for different purposes. Some of the major weaknesses that make it difficult to honour requests for financial reports in the country include the absence of a central balance sheet office and non-compliance with the requirement to submit financial statements to the court registry. With the exception of subsidiaries of international groups, very few businesses file their audited accounts since there is no control mechanism that obliges them to do so. With respect to ensuring the reliability and transparency of financial information from small and medium-sized enterprises (SMEs), there is no legal provision for the establishment of approved management centres (CGA). The World Bank's support for the computerisation of the regional Trade and Personal Property Credit register (RCCM) as part of the OHADA project mentioned above will thus contribute to improving the availability of financial reports and the legal security of financial transactions.

By law, three bodies are charged with the regulation of public enterprises: the Court of Accounts, the Inspectorate General of Finance of the Ministry of Finance and Budget, and the Ministry for Restoring Public Affairs and Good Governance. In practice, regulation of public companies in Chad is often inoperative and is burdened with cumbersome procedures that neither facilitates effectiveness nor efficiency. Generally speaking, oversight bodies are plagued by a lack of adequate, competent human resources and a paucity of financial resources.

The quality of accounting and auditing education needs to be enhanced, in order to meet the needs of the private sector. Indeed, in recent times in Chad, the number of private schools providing training in accountancy and finance professions has increased considerably, without any control and verification of the quality of teaching. Where the public accountancy curriculum is concerned, the CEMAC zone has not yet established a sub-regional public accountancy certification (diplome d'expertise comptable) as planned earlier, and one that is similar to the WAEMU DECOFI curriculum, which has also been approved by the African and Madagascan Council of Higher Education (CAMES). INTEC thus remains the main institution which trains students for the French public accountancy diploma. However, very few have actually obtained the diploma, due to the relatively poor calibre of students and the high cost of training.

Looking ahead, the major areas of focus in seeking to strengthen the legal and regulatory framework governing accountancy and auditing professions in Chad are the following: (i) the reclassification of CEMAC licensed accounting technicians in Chad in the category of public accountants, in accordance with community regulations, (ii) the establishment of a national association of chartered accountants, (iii) the proper functioning of the national accounting standards commission, (iv) the adoption of auditing professional standards and a code of ethics in line with those established by IFAC independent standard-setting board, (v) the strengthening of initial training through the improvement of the quality of the national curriculum and by drafting a continuous professional training plan, and (iv) the capacity building of the Court of Accounts to enable it implement INTOSAI auditing standards in order to ensure proper supervision of public enterprises. These activities should be included in Chad's national Accounting and Auditing ROSC action plan and must ensure synergy with other planned or on-going national activities in the area of public finance reforms as well as community-wide implementation of OHADA accounting law reforms.

The priority recommendations arising out of the Chad Accounting and Auditing ROSC are summarized in the table below indicating the activities to be implemented at the country and those that need to be implemented at the regional level. 


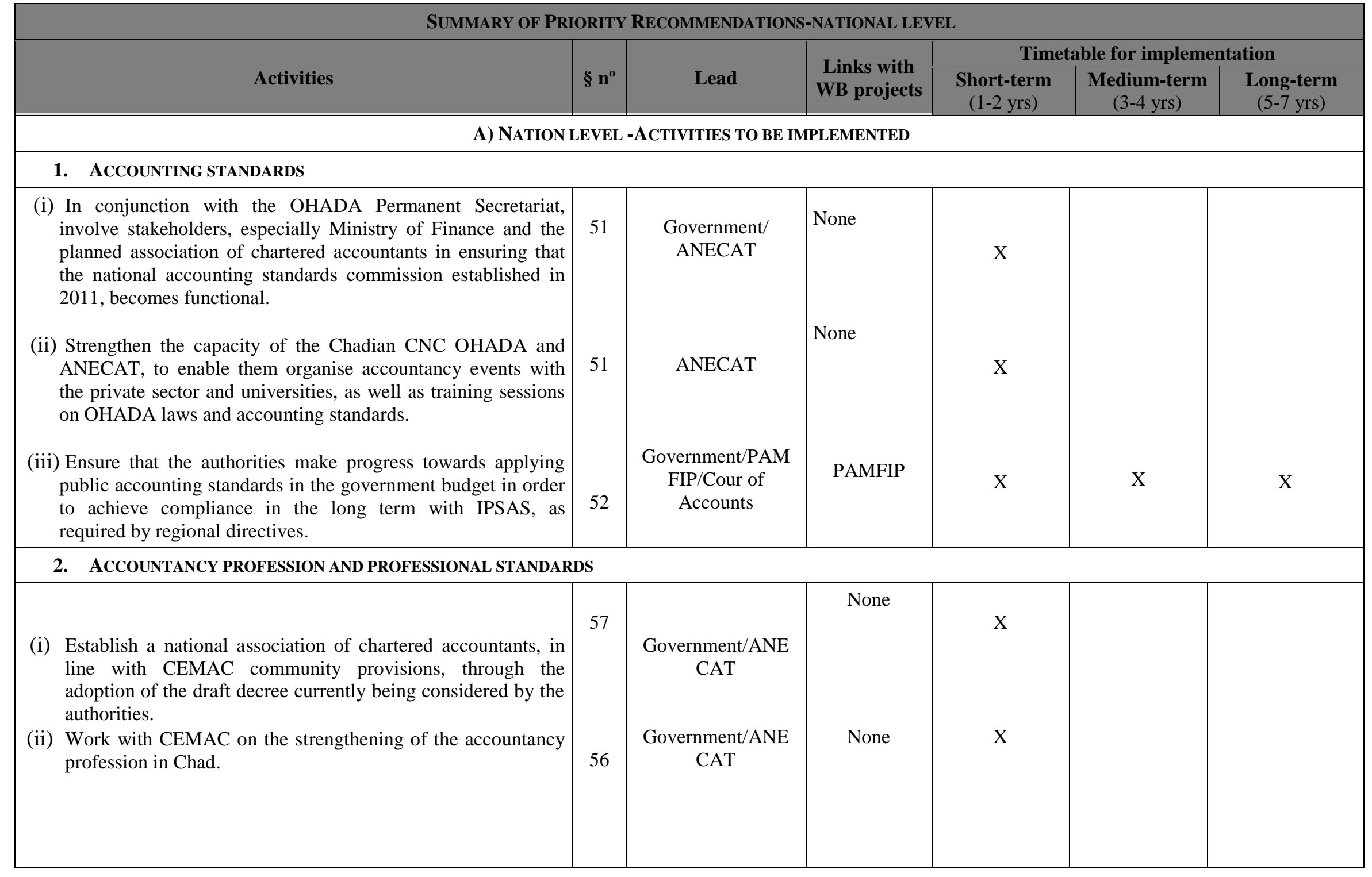




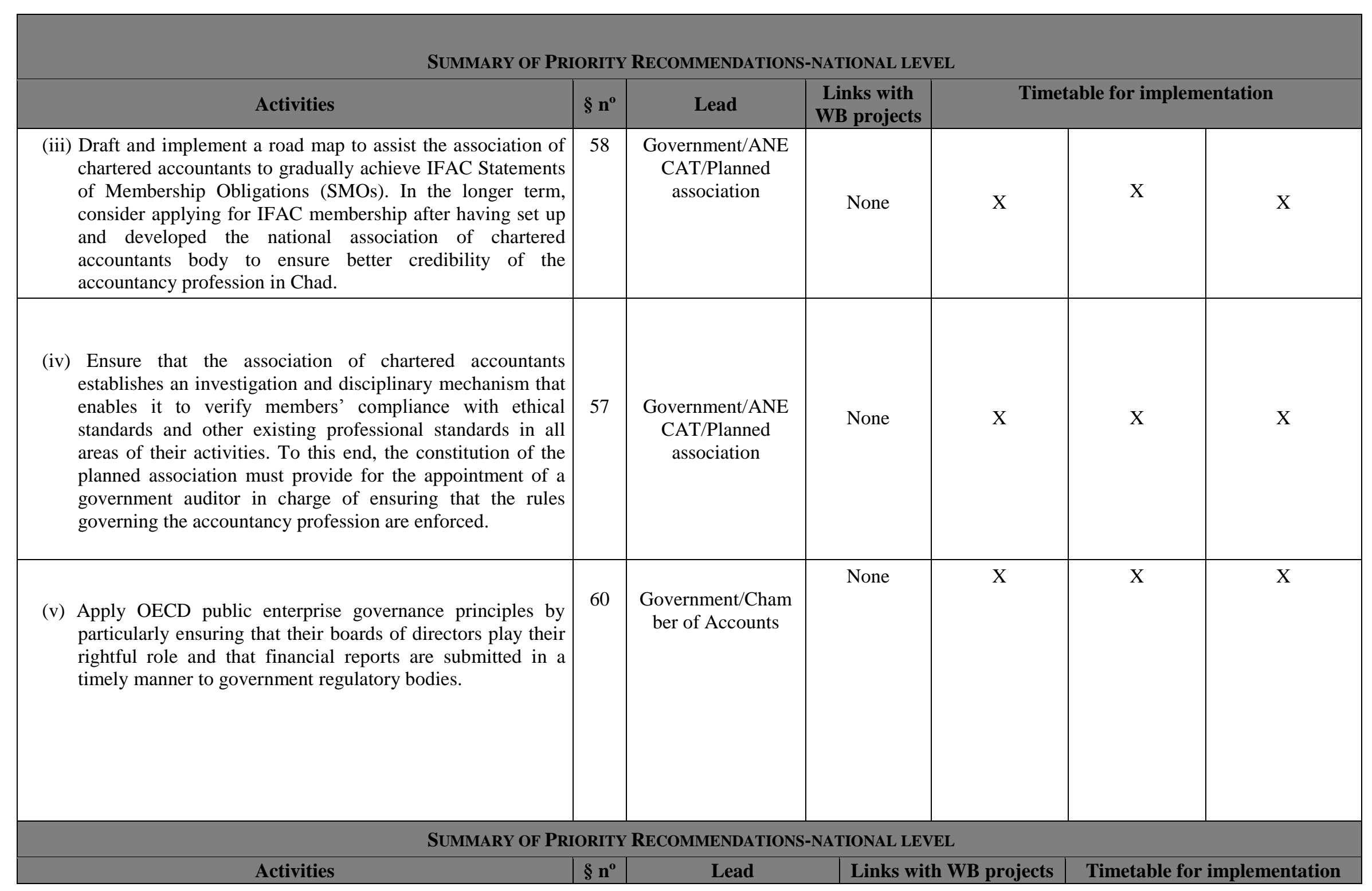




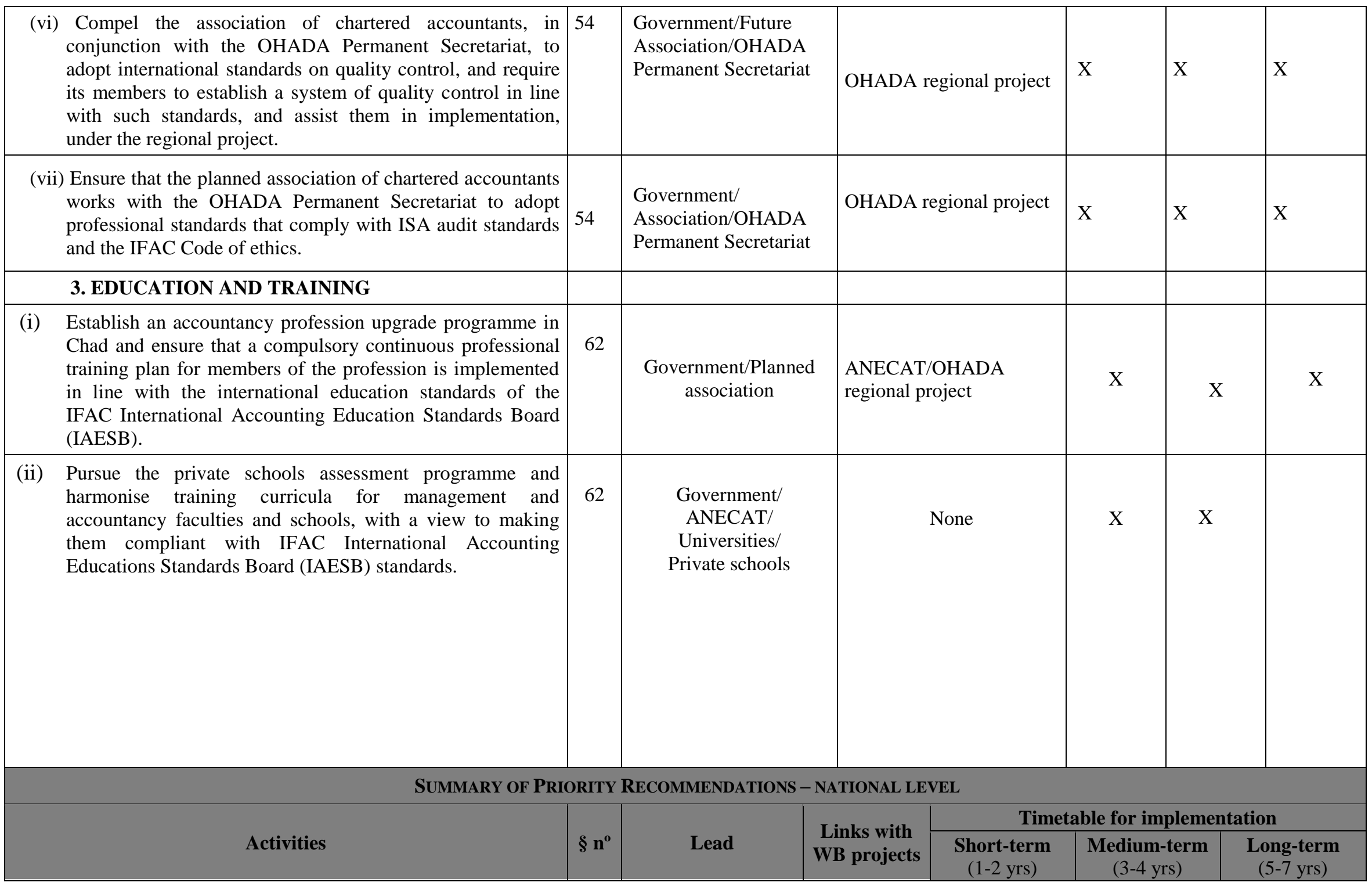




\begin{tabular}{|c|c|c|c|c|c|c|}
\hline & & & & $\begin{array}{l}\text { Short-term } \\
(1-2 \text { yrs })\end{array}$ & $\begin{array}{l}\text { Medium-term } \\
(3-4 \mathrm{yrs})\end{array}$ & $\begin{array}{l}\text { Long-term } \\
(5-7 \text { yrs })\end{array}$ \\
\hline $\begin{array}{l}\text { 4. ACCESS TO FINANCIAL AND ACCOUNTING } \\
\text { REPORTS }\end{array}$ & & & & & & \\
\hline $\begin{array}{l}\text { (i) Adopt texts to enable the setting up of CGAs through } \\
\text { public-private partnerships, with the involvement of the } \\
\text { Chamber of Commerce and the association of chartered } \\
\text { accountants. }\end{array}$ & 53 & $\begin{array}{l}\text { Government/ } \\
\text { Chamber of } \\
\text { Commerce/ } \\
\text { Association }\end{array}$ & None & $\mathrm{X}$ & & \\
\hline $\begin{array}{l}\text { (ii) Engage with the authorities in order to rationalise government } \\
\text { regulatory bodies and to strengthen the capacity of the Court } \\
\text { of Accounts to enable it supervise public enterprises. }\end{array}$ & 67 & Government & PAMFIP & $\mathrm{X}$ & & \\
\hline $\begin{array}{l}\text { (iii) Put in place the necessary material and human resources to } \\
\text { enable the Court Registry to function properly and facilitate } \\
\text { financial report collection and their access. Also set up an } \\
\text { electronic system of record keeping. }\end{array}$ & 66 & Government & $\begin{array}{l}\text { OHADA } \\
\text { regional project }\end{array}$ & $\mathrm{X}$ & $\mathrm{X}$ & \\
\hline $\begin{array}{l}\text { (iv) Formally create the steering committee to draft a plan of } \\
\text { reform activities related to the ROSC Accountancy and } \\
\text { Auditing. }\end{array}$ & 68 & Government & None & $\mathrm{X}$ & $\mathrm{X}$ & $\mathrm{X}$ \\
\hline
\end{tabular}


SUMMARY OF PRIORITY RECOMMENDATIONS -REGIONAL LEVEL

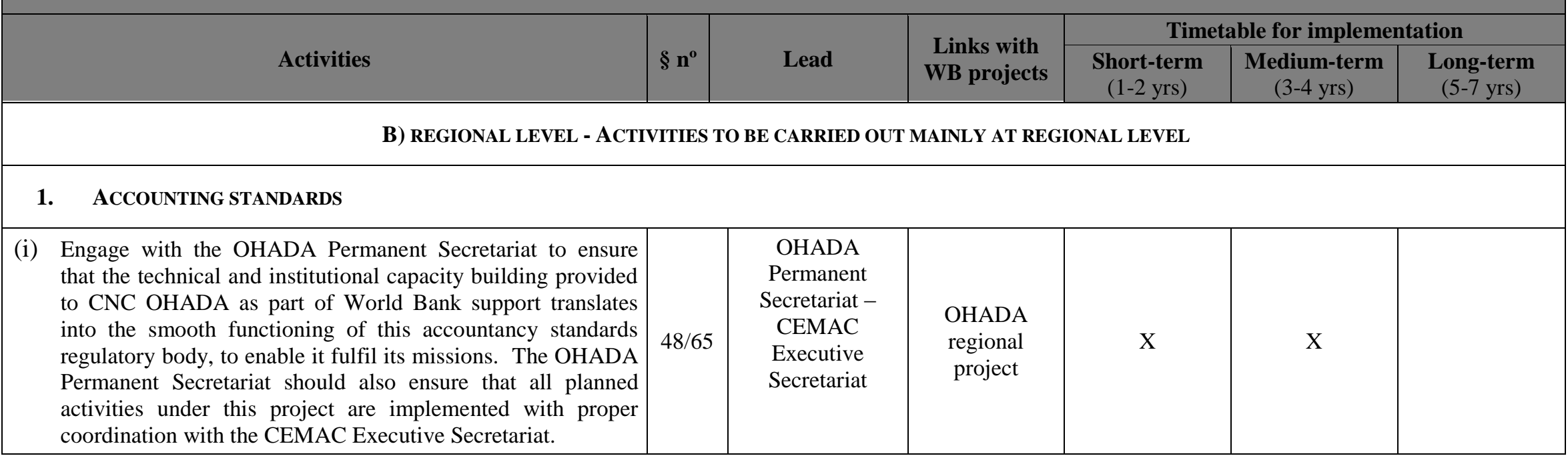




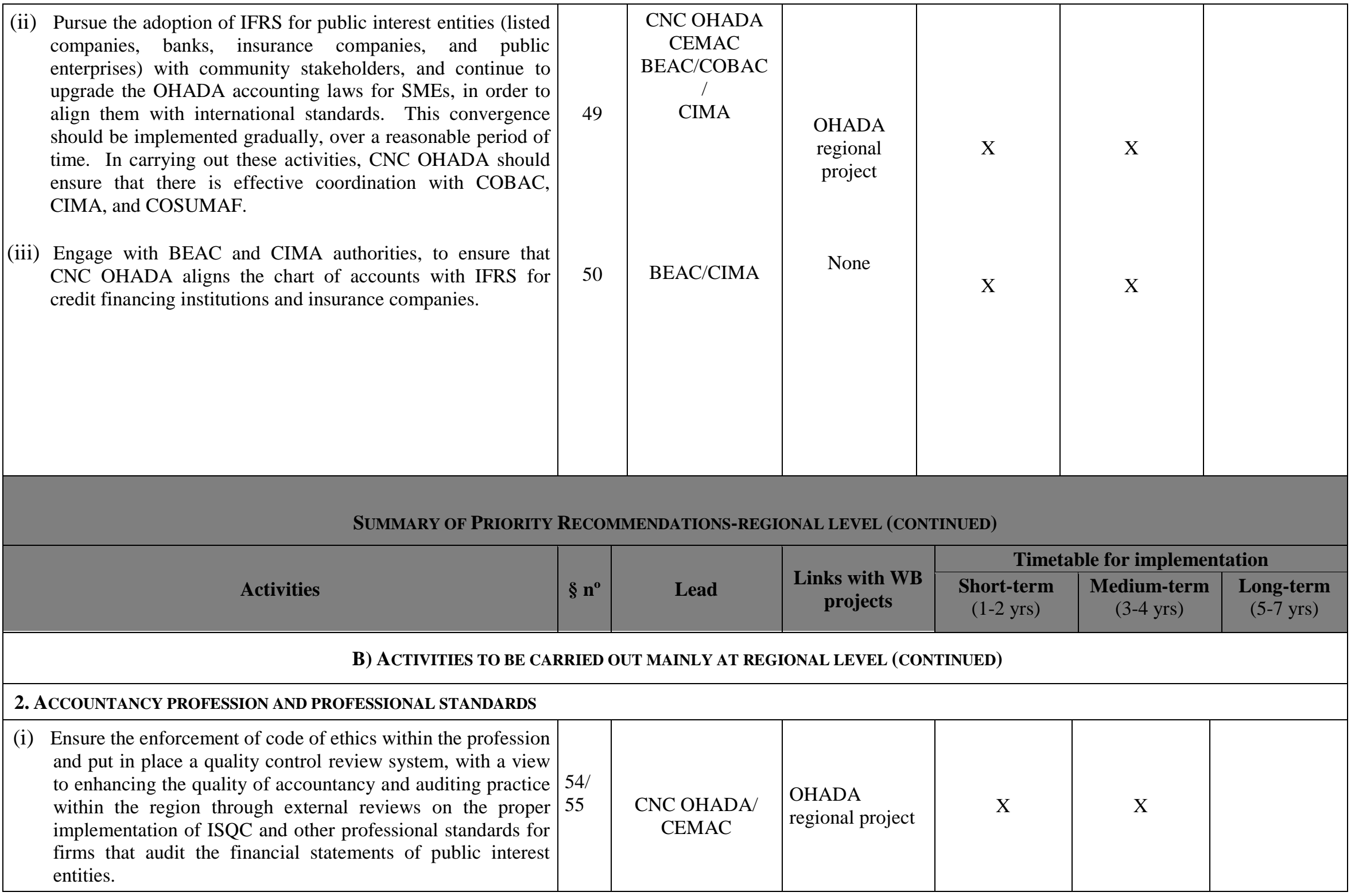




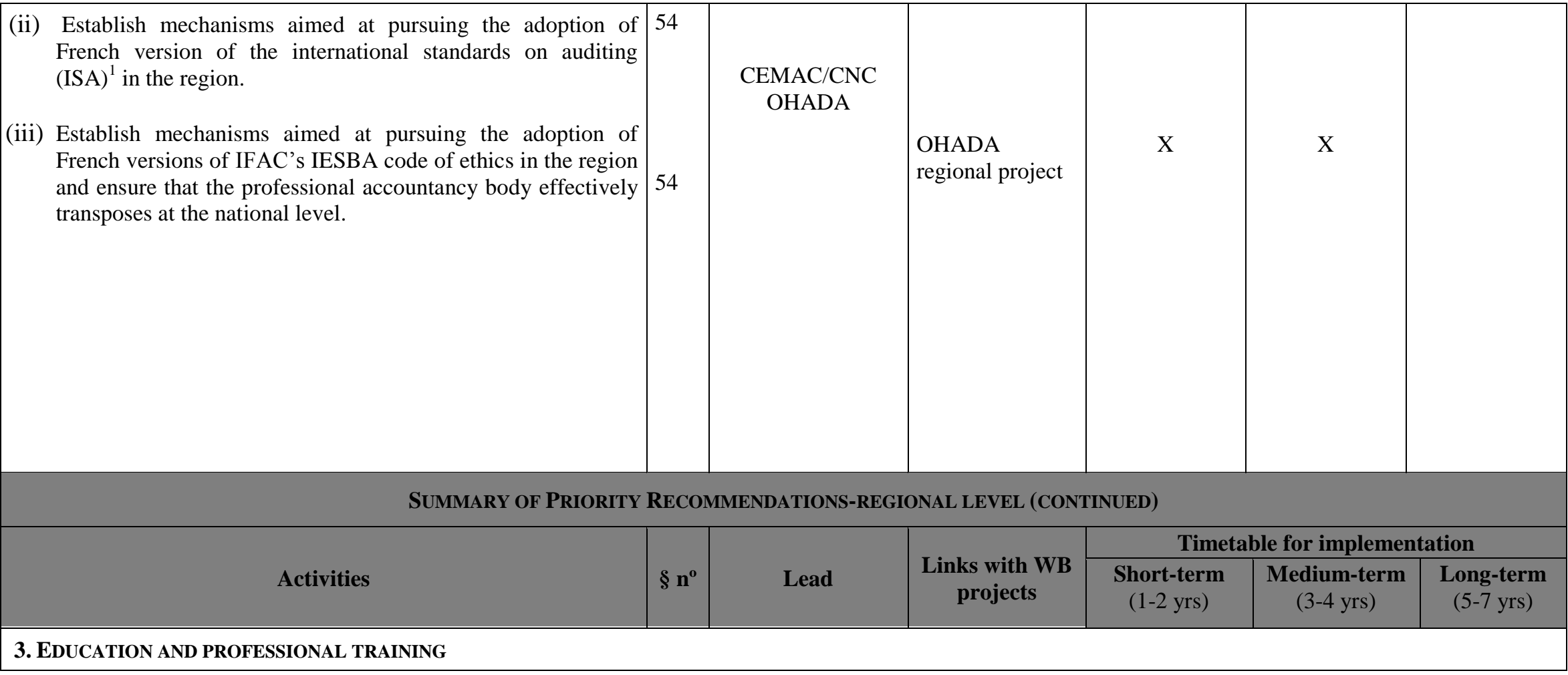

\footnotetext{
${ }^{1}$ Some IFAC members have produced a French language translation of the most recent version of the international standards on auditing, in line with the IFAC Translation Policy.
} 


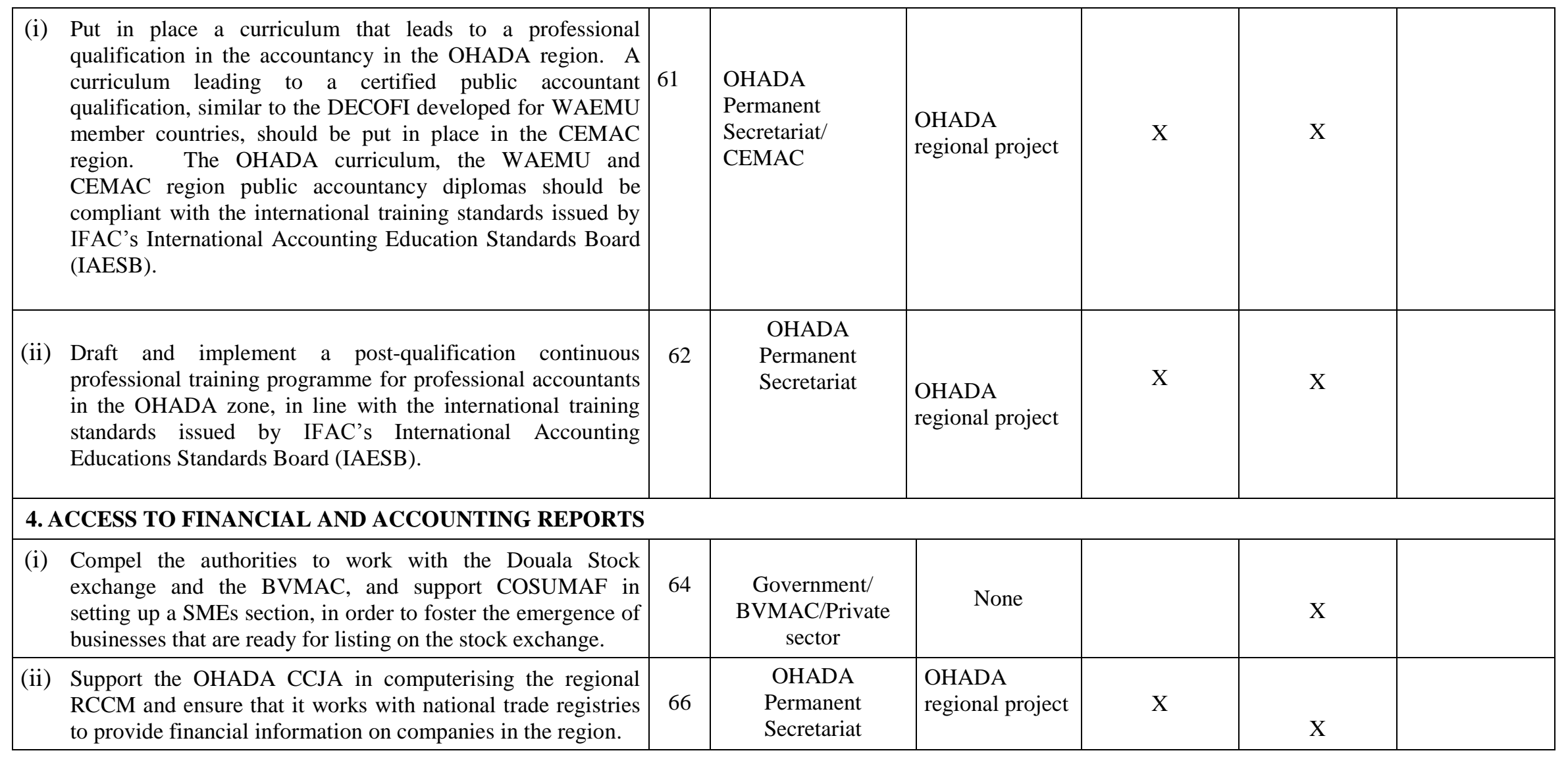




\section{ECONOMIC BACKGROUND}

1. Chad is a landlocked country located in Central Africa, with a low population density, but which is endowed with significant oil resources and arable land: With a surface area of 1284000 $\mathrm{km}^{2}$, Chad encapsulates the contrasts between the desert in the north and the savannah in the south. It is the fifth largest country in Africa, after Sudan, Algeria, the Democratic Republic of Congo, and Libya. Chad borders Sudan to the east, Cameroon, Niger and Nigeria to the west, Niger to the east, and Libya to the north. In addition to the oil sector, the country is endowed with considerable potential, particularly in the areas of agriculture and livestock. With the processing of the large oil deposits in Doba, in the southern part of the country, the share of the oil sector in the Chadian economy has increased significantly (between 2009 and 2010, oil exports increased by almost 25 per cent and represented about 30 per cent of GDP in 2010). The population of Chad is estimated at 11.2 million inhabitants, with a rather low average density of 6 inhabitants per square kilometre and a concentration of the population in the south ${ }^{2}$ and in the country's major cities (Ndjamena, Moundou, Sarh, Abeche, Faya Largeau, and Doba).

2. The per capita income in Chad is relatively lower than in the other CEMAC member countries. The country must therefore continue its efforts in improving the living standards of the population. Chad is one of the world's poorest countries. 85 percent of the country's population derive their livelihood from the agricultural sector, which generates about 40 percent of GDP in the form of subsistence agriculture, livestock, and fisheries. One half of the population of Chad lives below the poverty threshold. Chad's ranking at 165 out of 183 countries in the 2012 UNDP Human Development Index is a true reflection of the country's relatively low social indicators, which are indeed often far behind those of other countries in the sub-region. In recent years, the structural reforms undertaken by the authorities, in conjunction with the increase in oil prices, have considerably enhanced the economic and financial resources of the country. Chad's development however continues to be hampered by the fact that it is landlocked and thus has no access to the sea. It is also plagued by droughts, lack of infrastructure, and repeated political crises. Chad adopted a national poverty reduction strategy that promotes structural reform (budget sustainability, proper management of public finance, and optimum use of oil income to promote economic diversification and poverty reduction). The country has also embarked on a privatisation process aimed at improving the economy as a whole. However, it still faces difficulties in diversifying.

3. In 2003, the Chadian government began to implement a national poverty reduction strategy. Currently, the aim of the national poverty reduction strategy (SNRP $1 \&$ 2) and national development programme (PND) has been to meet the Millennium Development Goals by 2015. The priorities outlined in the National Development Plan focus on the following priorities: (i) creation of new productive capacities and opportunities for decent jobs; (ii) human capital development and the fight against inequality, poverty and social inclusion; (iii) environmental and climate change adoption; , (iv) improved governance. The review of the observance of accounting and audit standards is thus a major step towards improving financial governance.

4. Despite the fact that the Chadian government holds share capital in 2 banks, the financial sector is dominated by 6 subsidiaries of international group of companies. The use of banking services in the country remains very low. The aggregated balance sheet of the Chadian banking system, which comprises 8 credit institutions, was set at FCFA 673 billion at 31 December 2012, as compared to FCFA 577 billion the previous year. This represents a 16.6 percent increase. The volume of deposits held by these banks was estimated at FCFA 508 billion as at 31 December 2012. Government holds share capital in the 2 banks, the Banque Agricole et Commerciale and Commercial

\footnotetext{
${ }^{22}$ Just 2 percent of the population lives in the northern Sahara zone, which covers 45 percent of the national territory
} 
Bank Tchad. Despite the high liquidity of the banks (cash reserves of credit institutions reached 139 billion, as compared to 103 billion in 2011, an increase of 35 percent over the period), the country is still characterised by low use of banking services (estimated at about 2 percent of the population), and SMEs still face many difficulties in accessing credit. Networks are predominant in the micro-finance sector and represent about 92 percent of the activities of an estimated 170 existing micro-finance institutions (MFIs). By the end of December 2011 deposits held by MFIs reached FCFA 6.9 billion, while loans granted, were FCFA 7.5 billion. The insurance sector is not yet highly developed as it comprises only 2 non-life insurance companies, one of which also provides life insurance. Total premiums at 31 December 2011 stood at FCFA 7.6 billion.

\section{The Central African stock exchange, the Bourse des Valeurs Mobilières de l'Afrique Centrale} $(B V M A C)$ to which Chad is a member has just launched its first listing of a CEMAC zone company. This is the first of its kind since the stock exchange was established in August 2008. The Bourse des Valeurs Mobilières de l'Afrique Centrale (BVMAC) has the exclusive public service mission of organising, developing, and managing the regional financial market. In March 2013, it launched its first official listing of the SIAT Company from Gabon, which floated 30 per cent of its share capital on the Central African financial market ${ }^{3}$. This situation is due to the fact that the BVMAC has to deal with subsidiaries of international groups which dominate the economic fabric of CEMAC member countries. BVMAC also faces competition from the Douala stock exchange (DSX). Currently, the BVMAC cannot intervene in Cameroon, as a result of this competing presence. The mission entrusted to heads of State of CEMAC member countries by the African Development Bank, to bring about a reconciliation of the two stock exchange systems has not yet produced the expected results. To date, only the bonds department of the BVMAC functions relatively well and indeed the government of Chad recently issued a bond of 100 billion $^{4}$ CFA francs. Furthermore, during the meeting in Brazzaville in December 2010, 12 measures were adopted to give new impetus to the BVMAC. One of these measures concerns the establishment of an SME desk, similar to the Pre-listing Compartiment5 (PLC) which exists in the WAEMU Bourse Régionale des Valeurs Mobilières $(B R V M)$, and which serves as an "antechamber" for SMEs prior to their being listed on the stock exchange. This has not yet generated the desired impact.

6. With the establishment of a permanent technical secretariat for government disengagement in the Ministry of Trade, the para-statal sector is no longer predominant in the Chadian economy. Since 1990, the government has been committed to reducing the economic role of State by liberalising the economy and encouraging private sector development. The main objectives of this new policy are, amount others: (i) to reduce government participation in state and para-statal enterprises, (ii) To privatise those that are economically and financially profitable and liquidate those that are not viable, (iii) to promote the private sector and boost national production, and (iv) to improve the institutional and legal environment for business. Today, the State still holds shares in certain companies in sectors such as telecommunications (SOTEL Tchad), textiles (Société coton Tchad), water and electricity (STEE), cement production (SonaCimenterie), the hotel industry (Hôtel Méridien), banking (CBT), et cetera.

7. The Chadian private sector is hampered by constraints that should be removed as a prerequisite for its development. Some of the major obstacles to a sound business climate in the country include long-lasting political instability, inadequate basic infrastructure and quality public

\footnotetext{
${ }^{3}$ That is 1170000 shares issued for sale at FCFA 28500 per share. The subscription period was from 25 March to 10 May 2013. This company is the first to be listed on the sub-regional stock exchange through a capital increase, with the sale of 30 percent of its capital to the general in the Central African economic and monetary community.

${ }_{5}^{4}$ As at 31 December 2012, these bonds had been funded to the tune of FCFA 219579470000.

${ }^{5}$ Membership of the PLC implies compliance with the provisions of the OHADA system of accounting and a commitment to ensure transparency and financial reporting. The company publishes its sales figures every six months, as well as income trends, and the semi-annual and annual income statements.
} 
services, irregular power supply, a weak judicial system, and lack of adequately trained human resources. For the Chadian private sector to develop, these constraints need be addressed. According to the Doing Business report, these are serious constraints, which contributed to ranking Chad last out of 183 countries in 2012, with regard to the ease of doing business in the country. The main employers' organisation is the Conseil National du Patronat Tchadien (CNPT), which brings together about 75 companies, including major international groups of companies. This situation shows that the national private sector is poorly organised, and that the informal sector is predominant. Indeed, statistics provided in the 2012 edition of the CNPT White Paper referred to the existence of 8282 companies in the country ${ }^{6}$. Government has made attempts to take into account the concerns expressed by businessmen, but the measures taken are still considered timid by employers. One example was the establishment of a permanent framework for dialogue in 2008, known as the "Government-Private sector forum for dialogue" (FODEP). The mission of this body is to bring about reforms of the legal, administrative, financial and judicial frameworks, as well as to adapt the tax system to the needs of businesses.

8. Chad is a member of various sub-regional economic, legal, and financial organisations. The country thus belongs to various organisations that are key players in regulating accounting and auditing standards in Central Africa. These organisations include:

- The economic and monetary union agreements within central Africa, through CEMAC, which in 1994 replaced the customs union treaty, signed in 1964 . CEMAC member countries use a single currency, issued by the central bank, the Banque des États d'Afrique Centrale $(B E A C)$. There is also a single banking sector oversight body, the Central African banking commission (COBAC).

- The treaty establishing OHADA. This organisation comprises the six CEMAC countries, the eight member states of the West African economic and monetary union (WAEMU) ${ }^{8}$, Comoros, Guinea, and the Democratic Republic of Congo. The main organs of the organisation are the Permanent Secretariat in Yaounde and the supreme judicial body responsible for all disputes related to the OHADA law, the Cour Commune de Justice et d'Arbitrage (CCJA), based in Abidjan. The Uniform Acts (UA) co-signed by all 17 statesparties are legally enforceable in each state. The main legal provisions governing accounting and auditing in Chad are established by two OHADA Uniform Acts (cf. paragraph 8).

- The Conférence Interafricaine des Marchés d'Assurances (CIMA), which brings together the CEMAC and WAEMU member states (a total of 14 countries). ${ }^{9}$

- Economic Country Community of Central Africa (Communaute Economique des Etats de l'Afrique Centrale-CEEAC) which comprises ten member states: Angola, Burundi, Cameroon, Central African Republic, Republic of Congo, the Democratic Republic of Congo, Gabon, Equatorial Guinea, Sao Tome \& Principe and Chad.

\footnotetext{
${ }^{6}$ The private sector in Chad includes 8282 businesses that can be classified as follows, in fiscal terms: 7000 businesses in the non-assessable system, 810 in the streamlined system, and 472 in the real profit system, with half of these representing 70 to 80 percent of national fiscal revenue.

7 Traité de l'Union Douanière et Économique d'Afrique Centrale (UDEAC). CEMAC is the successor to the UDEAC. It member-States are Cameroon, Central African Republic, Chad, Congo, Gabon, and Equatorial Guinea. The headquarters of the Executive Secretariat of CEMAC are in Bangui (Central African Republic).

8 Benin, Burkina-Faso, Côte d'Ivoire, Guinea Bissau, Mali, Niger, Senegal, and Togo

9 Treaty of 10 July 1992, establishing an integrated insurance industry organisation in African member countries in the Franc zone, and establishing the Inter-African conference on insurance markets. The headquarters of CIMA are in Libreville (Gabon).
} 


\section{LEGAL AND INSTITUTIONAL FRAMEWORK}

\section{A. Accounting and Auditing Legislation and Regulations}

9. The requirements with regard to corporate accounting and filing of accounts, as well as statutory regulatory (external audit) in Chad are enshrined in various national, sub-regional, and international texts. They are summarized in the table below and analysed in detail in the ROSC reports of WAEMU and CEMAC countries.

\begin{tabular}{|c|c|c|c|c|}
\hline $\begin{array}{c}\text { Corporate } \\
\text { structure/ } \\
\text { Activity sector }\end{array}$ & $\begin{array}{c}\text { Annual } \\
\text { accounts }\end{array}$ & External audit & $\begin{array}{l}\text { Filing of } \\
\text { accounts }\end{array}$ & Publication \\
\hline \multirow{3}{*}{$\begin{array}{l}\text { Commercial } \\
\text { companies (SA, } \\
\text { LLC) - Economic } \\
\text { interest groupings } \\
\text { (GIE)- State } \\
\text { enterprises and } \\
\text { para-statal } \\
\text { companies }\end{array}$} & \multirow{3}{*}{$\begin{array}{c}\text { OHADA } \\
\text { accounting law }\end{array}$} & $\begin{array}{l}\text { Mandatory for } \\
\text { corporations } \\
\text { (SA) }\end{array}$ & \multirow{3}{*}{\multicolumn{2}{|c|}{$\begin{array}{c}\text { Corporations have an obligation to } \\
\text { file accounts at the registry of the } \\
\text { court in charge of commercial } \\
\text { affairs } \\
\text { (Not enforced, in practice) }\end{array}$}} \\
\hline & & $\begin{array}{l}\text { Mandatory for } \\
\text { LLCs beyond a } \\
\text { certain size }\end{array}$ & & \\
\hline & & Optional for GIE & & \\
\hline Credit institution & $\begin{array}{c}\text { COBAC } \\
\text { accounting plan }\end{array}$ & $\begin{array}{c}\text { Mandatory } \\
\text { (COBAC- } \\
\text { approved auditor) }\end{array}$ & With COBAC & Not required \\
\hline $\begin{array}{l}\text { Insurance } \\
\text { companies }\end{array}$ & CIMA code & Mandatory & $\begin{array}{l}\text { With the } \\
\text { CRCA }\end{array}$ & Not required \\
\hline
\end{tabular}

10. The fiscal obligations placed on business companies are described under articles 28, 29, and 30 of the General Tax Code. With regard to profit, taxpayers and companies whose turnover exceeds FCFA $200000000{ }^{10}$. are required to declare their net profit amount for the current and the previous year to the tax administration in Chad before 31 March each year. According to the terms of article 29, the tax declaration form should be filed together with two copies of the balance sheet, the operating statement, their income statement, and the statement of sources and application of funds. In line with community requirements, companies are required to submit a statistical and fiscal statement (DSF) comprising a balance sheet, an income statement, a statement of sources and application of funds, and activity statistics of the company. The DSF template of the CEMAC system, harmonised with OHADA accounting law, was adopted by regulation $\mathrm{N}^{\circ}$ 08/11-UEAC 210 -CM-22 of 19 December 2011. It was also noted that due to the lack of preparation and submission of the DSF, the DGI has introduced in the 2015 financial law, a new format and content of the DSF similar to the CEMAC model. It comprises the annexes required by the SYSCOHADA plus those required by the CEMAC directives. The CEMAC Commission has also been given the mandate of drafting a DSF for the simplified and minimal cash-basis systems. Funding for this is expected under the $10^{\text {th }}$ EDF RIP.

11. The Central African financial market oversight commission (COSUMAF) oversees and regulates the regional financial market. As the competent authority in charge of market regulation

\footnotetext{
${ }^{10}$ The new threshold is FCFA 100 million according the 2014 fiscal law for taxpayers subject to the normal system. The objective is to align companies' turnover threshold with the thresholds for tax on profit (IS, BIS, BNC).
} 
and control, COSUMAF is has three main roles under the terms of the legal provisions governing the regional financial market. These include to (i) ensure the protection of funds invested in securities and other financial instruments that may be issued as part of initial public offerings; (ii) provide information to investors, and (iii) ensure the smooth functioning of the market. Companies that wish to issue shares on the stock market, and whose equity capital exceeds FCFA 500 million (for compartment A) and FCFA 200 million (for compartment B) [SMEs-SMIs] are required to provide audited financial statements reports for the past two financial years. Listed companies are also obliged to appoint two statutory auditors. The obligations regarding regular reporting by issuing companies to the market and oversight bodies are set out under the general regulations of the BVMAC. In particular, the quotation must be published in the Official Bulletin, and semi-annual and annual statements must be published in a journal of legal notices.

12. By law, 3 bodies have oversight of public enterprises: the Court of Accounts, the Inspectorate General of Finance of the Ministry of Finance and Budget, and the Ministry for Restoring public affairs and Good Governance. The Chamber of Accounts of the Supreme Court was created by organic statute $n^{\circ} 006 / \mathrm{PR} / 98$ of 23 , establishing the attributions, organisation, and functioning of the Supreme Court. Article 122 of this law stipulates that the Chamber of Accounts has financial jurisdiction with oversight role over the accounts prepared by Public Accountants, and also assists government and Parliament in regulating and overseeing the execution of finance laws. Under the terms of article 130 of the same law, it may also verify the accounts and the management of corporate bodies in which the State or any other bodies already under the direct control of the Chamber, separately or jointly, hold shares capital that confer upon them decision making power. With the lack of sufficient human ${ }^{11}$, financial, and material resources, it is clear that the Chamber of Accounts is currently incapable of properly overseeing the activities of state enterprises ${ }^{12}$. Following the recent constitutional amendment, the Chamber of Accounts has been transformed into a Court of Accounts with full-fledged jurisdictional powers, in accordance with CEMAC directives. However, this Court of Accounts was not effective and the President of the Court and the key officials were not appointed yet at the time of the finalization of this study. Where the Ministry for Restoring public affairs and the Promotion of good governance is concerned, article 15 of decree $\mathrm{N}^{\circ}$ 696/PR/PM/MCCGEM/2005 of 20 September 2005, is still in force, stipulates that it shall inspect, control, and take measures to ensure moral rectitude in the activities of state enterprises. There are about 150 inspectors and comptrollers employed by the Ministry, but often with inadequate competences. The Inspectorate General of Finance (IGF) is governed by decision $\mathrm{N}^{\circ}$ 042/MF/SE/IGF/02, establishing the attributions and organisation of the inspectorate. Its missions include controlling, verifying, and auditing state and para-statal enterprises. It has powers to carry out records-based or on-site verification of the accounting, audit the financial statements, oversee budget execution, and make pronouncements on the profitability and viability of such enterprises. The analysis shows however that the control of state enterprises in Chad is often inoperative and is burdened with cumbersome procedures that do not contribute to effectiveness or efficiency. Generally, oversight bodies are plagued by a lack of adequate, skilled human resources and a paucity of financial resources.

13. There has been a strong demand from the private sector, the tax Administration, and central bank authorities for the establishment of a central balance sheet office, which would provide a single, harmonised, accounting and financial data set to all users of financial reports. The existence of such a central balance sheet office would facilitate: (i) enhanced analyses of the financial performance and prospects of businesses, as a tool to guide decision-making in management, investment, and granting of loans; (ii) more secure business relations, and (iii) support financial market operations by providing a source of reliable accounting and financial data. Under the current practice, businesses draft different financial statements for different purposes, thus making it difficult to obtain real figures to make estimates on national macro and micro economic data. The creation of

\footnotetext{
${ }^{11}$ There are only 5 public auditors at the Chamber of Accounts.

${ }^{12}$ Financial statements of State enterprises are not filed with the Chamber of Accounts.
} 
Balance sheet database was initiated five years ago and arrangements have been put in place to make available this information by the BFAC. It was agreed that this database will be updated by December 31, 2015 with the information related to the balances sheet of the fiscal years closed on December 31, 2011 and 2012.

14. While in the past, the country attempted to set up a mechanism to provide assistance to SMEs with the support of the IFC, we are forced to note today that there is no legal mechanism similar to the approved management centres (CGA) in place to assist and supervise small and medium-sized enterprises (SMEs) as well as very small enterprises (VSEs) in the area of management and accounting. In 2004, the Chamber of commerce, industry, agriculture, mines, and crafts, established a centre for business development In Ndjamena (CCIAMA) with the support of the IFC. The objective of the centre was to assist SMEs in accounting and in drafting business plans, in order to enable them apply for bank loans. Under the programme, 252 enterprises were evaluated, and 52 heads of SMEs were trained and benefited from subcontracts to the tune of FCFA 20 billion. It appears that the country has recently adopted a national strategy for the development of SMEs. Furthermore, the CCIAMA is currently assessing the feasibility of establishing CGAs. The accountancy profession is also interested in the project and would be willing to assist in drafting a bill on the promotion and development of SMEs in Chad, to be submitted to the authorities for adoption.

\section{A. The accountancy profession in Chad}

15. Due to the fact that CEMAC guidelines in this area have not been transposed at the national level, there are no national regulations in place governing the accountancy profession. Although the Accountancy profession in Chad is governed by various CEMAC texts ${ }^{13}$, no national law has been adopted to establish an association of chartered accountants. The existence of a professional accountancy body is now common practice internationally and is indeed compulsory within the CEMAC region. The authorities and the professional accountants are now taking steps to establish a national professional association, in line with the provisions of article 4 of regulation $n^{\circ} 11 / 01$-UREC027-CM-07 of 5 December 2001, revising the status of independent professional accountants. To this end, a draft text regulating the profession has been submitted to the authorities for consideration and adoption. In line with UEAC directions, the draft text describes (i) the conditions for practicing the accountancy profession as an independent professional, (ii) the administration and organisation of the national accountancy professional body, including its role in regulating the profession, and (iii) the general provisions. The establishment of the professional accountancy body is an absolute necessity if the accountancy profession is to develop significantly in Chad. It would in particular make it possible to establish an important basis for enhancing the credibility of the profession by developing initial and continuous professional training in accountancy; assisting its members in applying accounting and auditing standards as well as the code of ethics nationally; developing quality assurance, and generally observing the relevant ethical principles. Auditing activities in Chad are mainly related to statutory auditing of the accounts of business enterprises, banks, insurance companies, subsidiaries of foreign companies, and financial audits of donor funded projects. These missions are mainly carried out by audit firms with their headquarters in Cameroon. In addition, in the absence of a professional

13 Act $N^{\circ}$ 4/70-UDEAC-133 of 17 November 1970, establishing the status of Public Accountant; Regulation $n^{\circ}$ 11/01-UREC-027-CM-07 of 05 December 2001, revising the status of independent accounting professionals; Decision $N^{\circ}$ 29/01/UEAC-027-CM-07 of 05 December 2001, setting the conditions for reclassifying licensed accountants in the category of public accountants; Decision N ${ }^{\circ}$ 30/01-UEAC-027-CM-07 of 05 December 2001, establishing a joint committee for the supervision of the accountancy profession in the CEMAC zone. This committee is in charge of supervising the activities of independent professional accountants and the quality of service, in line with international standards and community regulations, as well as ensuring that quality control is carried out for each licensed accountant at least once every three years. This control is however lacking. 
accountancy association, the accountancy profession is exercised illegally ${ }^{14}$ to a large extent, with accounting records that do not conform to the relevant CEMAC requirements.

16. Accounting technicians accredited by the High Court in Ndjamena have come together to form the Association des Experts comptables et Comptables agréés du Tchad (ANECAT). The situation in Chad is characterised by the fact that very few accounting technicians have received CEMAC accreditation in line with the provisions of article 2 of regulation $n^{\circ} 11 / 01$-UREC-027-CM07 of 5 December 2001, revising the status of independent accounting professionals. Indeed, Public Accountants who are authorised to practice in Chad must be accredited by the UEAC Council of ministers, which is part of CEMAC. In Chad, one Chadian national who was trained in France as a Certified Public Accountant is accredited as a Chartered Accountant and 22 accounting technicians have recently been accredited by the CEMAC. The level of qualification of these accredited accounting technicians nevertheless varies to a large degree, and in practice is still below the international requirements. As indicated in paragraph 18 above, a period of 10 years had been set to reclassify accredited accounting technicians in the category of Accountants. This situation led to practising accountants and accounting technicians in the country setting up the ANECAT, the association that was created in 2010. The association comprises accounting technicians accredited by the Commercial Court of Ndjamena (individuals) and who work as independent professional accountant. As at 31 December 2012, it had about 50 individual members, most of who had been working in firms for several years. The accreditation process of the Court does not clearly define the conditions of training and competence to be met prior to obtaining such approval. The only major international auditing firm ${ }^{15}$ in Chad is not a member of ANECAT. As a result, the auditing profession in Chad is characterised by the existence of numerous practitioners who provide accounting and auditing services illegally, in violation of community regulations, and whose qualifications are often do not meet the set international standards ${ }^{16}$. The creation of an accountancy body is an essential prerequisite for ensuring the existence of a viable and credible accountancy profession in Chad. .

17. ANECAT is a non-profit association governed by Order $\mathbf{N}^{\circ} 27 / \mathrm{INT} / \mathrm{SUR}$ of $28 \mathrm{July} 1962$ on associations in the Chad Republic, and approved under number 3850 of 30 April 2012. The main goal of the association is to bring together accounting and auditing professionals in the Republic of Chad, to defend the interests of accountancy professionals, promote the practice of accounting as an independent profession, collaborate with the public authorities in defining training programs and organising professional accountancy exams, and to make suggestions to the public authorities regarding the developments in the accountancy profession. ANECAT has a constitution and by-laws. It also has two decision-making organs: the General Assembly, and the Executive Board. The general assembly is an annual general meeting of all members in good standing with regard to their professional contributions. The meeting elects the Executive Board, which is made up of nine members; the president, the vice-president, the secretary general, the assistant secretary general, the treasurer, the assistant treasurer, and three advisers. To become a member, one has to be a certified public accountant, a licensed public accountant, or an accredited accounting technician. ANECAT's activities are currently focused mainly on establishing a National Association of Chartered Accountants in Chad. A draft text to this effect has been submitted to the authorities and appears to be considerably advanced in the administrative process of adoption.

18. Conditions for CEMAC accreditation for accounting technicians and public accountants are defined under article 3 of regulation $n^{\circ}$ 11/01-UREC-027-CM-07 of 5 December 2001, revising the status of independent accounting professionals: in order to be accredited by the UDEAC Council of ministers, one must be a national of one of the respective member State, at least 25 years of age, of good moral standing, and a holder of a diploma in public accountancy or an equivalent accountancy diploma issued or recognised by the relevant authorities in the candidate's country of origin (article 3 of the abovementioned Regulation). Decision N ${ }^{\circ}$ 29/01/UEAC-027-CM-

\footnotetext{
${ }^{14}$ Sanctioned under article 20 of Regulation $n^{\circ}$ 11/01-UREC-027-CM-07 of 5 December 2001

${ }^{15}$ Ernst \& Young purchased the Henry firm in 2012

${ }^{16}$ Some bookkeepers have two years post-secondary education and were given approval by the Ndjamena court
}

Chad - ROSC Accounting and Auditing 
07 of 5 December 2001, establishing the conditions for reclassifying accredited accounting technicians in the category of Public Accountants stipulated a transitional period for CEMAC-accredited accounting technicians. A 10-year period was established under article 4 of the decision to reclassify such accredited accounting technicians, up to 5 December 2011. The deadline was subsequently extended to 31 December 2012 by decision $N^{\circ}$ 07/11-UEAC-027-CM-22 of the Council of ministers on 19 December 2011. The decision No 38/12-UEAC-010-CCM-23 already included a list of 23 accredited accounting technicians from Chad. The second list following the decision No 09/13-UEAC010-C-CM-SE dated on April 12, 2013 included 37 new accredited accounting technicians given a total number of 60 accredited accounting technicians. Following the 2013 exam in December 2013, 45 were reclassified Public Accountants leading to a total of 46 chartered accountants as of today taking into account the only one chartered accountant from France. Most of accredited accounting technicians that have been reclassified in the category of chartered accountants have more than 10 to 20 years of work experiences and have met the CEMAC eligibility criteria and exams. With the upcoming creation of the accountancy body, mandatory continuing professional trainings will help to update the capacity of these new chartered accountants.

19. National authorities and ANECAT must strengthen the legal and institutional framework to facilitate the development of a professional accountancy organisation, in accordance with the IFAC SMOs. The establishment of a recognised professional association is essential for promoting financial reporting in the country; ensuring proper initial and continuous training for accounting and auditing professionals; facilitating the enforcement of accounting and audit standards and ethics; ensuring regulation of the profession by establishing a disciplinary mechanism and a system of quality assurance. The latter could be reviewed at the regional level by CEMAC for auditing public interest entities. Members of the profession should be encouraged to join international accountancy organisations such as the Fédération Internationale des Experts Comptables Francophones (FIDEF) ${ }^{17}$ and Fédération Régionale des Réviseurs et Experts Comptables de l'Afrique Centrale (FRECAC) ${ }^{18}$ since these organisations support the development of the accountancy profession and encourage sharing of accounting and auditing best practices. Moreover, given that the accountancy profession is still in its nascent stage of development, it would benefit immensely from a mentoring arrangement from a well-developed Professional Accountancy Organization in the WAEMU or CEMAC region. The authorities should initiate a process aimed at ensuring that in the long run the National Association of Chartered Accountants complies with all seven IFAC SMOs. Establishing a disciplinary committee within the National Association of Chartered Accountants would ensure that all members of this association adhere to the ethical standards and other professional standards in carrying out their professional activities. This committee, which should include a government auditor as one of its members, could also deal with cases of illegal practice in the profession. The committee should be established in accordance with the requirements of IFAC Statements of Membership Obligations (SMO 6). For Chad to become a member of IFAC, it would be required to enforce of the seven Statements of Membership Obligations, as well as compliance with all of the organisation's other membership criteria. The table below summarises the country's situation with regard to the obligations defined under the IFAC SMOs:

\begin{tabular}{ll}
\hline SMO & Assessment of the ROSC team \\
\hline SMO 1- Quality assurance & Firms that are affiliated to international networks do \\
& carry out internal quality assessments. There are \\
& however no ISQC 1 and ISA 220 compliant \\
professional standards in place. The profession has \\
not yet organised any training activities on quality
\end{tabular}

\footnotetext{
${ }^{17}$ FIDEF is a forum for dialogue and cooperation among Francophone accounting professional bodies and is recognised by IFAC. It has drawn up a strategic plan to assist its members in attempting to implement the SMOs. ${ }^{18}$ The aim of FRECAC is to promote development and coordination in the accountancy profession in the Central African sub-region. It was established in November 2008 by the professional bodies of Cameroon, Central African Republic, Congo, Gabon, and the Republic of Congo.
} 
SMO 2 - International education standards and other Pronouncements issued by the International Accounting Education Standards Board (IAESB)

assurance. Generally, there is no formal system of quality assurance within the profession. To date, no external system of quality assurance has been put in place, and ANECAT has limited competence in its scope of activities.

Some existing texts ${ }^{19}$ provide for a curriculum leading to a CEMAC public accountancy diploma qualification. In reality, very little progress has been made towards establishing an accountancy training programme similar to the DECOFI, which exists for the WAEMU countries. International firms usually organise internal training programmes for their staff. The scope of such training programmes remains limited, and they are not compulsory for all members of the accountancy profession. As a result, the IAESB criteria of 120 hours of continued training over three years are not applied across the board. It should be noted that, in 2012, with the support of the World Bank, ANECAT organised three 40-hour training sessions, representing a total of 120 hours.

\begin{abstract}
SMO 3 - International standards and other Pronouncements issued by the International Auditing and Assurance Standards Board (IAASB)
\end{abstract}

SMO 4 - International Accounting Education Standards Board (IAESB) Code of Ethics for professional accountants
Auditing standards have not yet been adopted within the CEMAC region or nationally. In practice, professionals apply the professional standards adopted in France, albeit with numerous inadequacies. To date, there is no specific implementation guide available to facilitate their application in Chad.

Existing texts (article 5 of CEMAC Regulation of 5 December 2001) call for national associations to adopt and enforce a code of ethics. However, in the absence of a national association of chartered accountants, the code of ethics has not been adopted, and ANECAT has limited competence in its scope of activities.

\begin{tabular}{|c|c|}
\hline $\begin{array}{l}\text { SMO 5 - International Public Sector Accounting } \\
\text { Standards and other Pronouncements issued by } \\
\text { the International Public Sector Accounting } \\
\text { Standards Board (IPSASB }{ }^{20} \text { ) }\end{array}$ & $\begin{array}{l}\text { Public sector accounting standards are regulated at } \\
\text { community level by the CEMAC, which has } \\
\text { adopted a number of texts, including } 6 \text { directives }{ }^{21} \text {. } \\
\text { The texts on public accounting are aimed at moving } \\
\text { towards application of IPSASB international public } \\
\text { sector accounting standards (IPSAS). PAMFIP, } \\
\text { which was established by decree } \mathrm{N}^{\circ} 784 / \mathrm{PR} / \mathrm{PM} / / 06 \\
\text { of } 23 \text { August } 2006 \text {, has initiated steps in the country } \\
\text { to ensure the adoption of CEMAC directives on } \\
\text { public financial management. }\end{array}$ \\
\hline SMO 6 - Investigation and Discipline & $\begin{array}{l}\text { In the absence of a national association of chartered } \\
\text { accountants, there is no investigation and discipline } \\
\text { mechanism in place to ensure that accounting } \\
\text { professionals enforce and adhere to ethical }\end{array}$ \\
\hline
\end{tabular}

19 Such as Act $N^{\circ}$ 6/73-UDEAC-161 of 22 December 1973, adopted by the Council of Heads of State and reforming the programme of advanced accountancy examinations and Act $\mathrm{N}^{\circ}$ 4/89-UDEAC-161 of 13 December 1989 reorganising advance accountancy examinations and their enabling modalities, which were adopted in CEMAC

${ }^{20}$ IAASB, IAESB, IESBA, and IPSASB are IFAC standard-setting boards

21 In the CEMAC zone, there are general rules on public accounting (Directive $\mathrm{n}^{\circ}$ 02/08-UEAC-190-CM-17) and a government accounting plan (Directive $\mathrm{n}^{\circ}$ 05/08-UEAC-190-CM-17) 
standards and other professional standards in carrying out their professional activities. The ANECAT constitution however provides for the establishment of a disciplinary board, which is not yet operational. At regional community level, there are no mechanisms in place to sanction the illegal practice of the profession. The future national association of chartered accountants should include a government auditor as member of its committee in order to ensure the proper functioning of its various organs, as well as the investigation and discipline mechanisms.

\begin{tabular}{ll}
\hline SMO 7 - International Financial Reporting & The financial reporting standards currently in force \\
Standards & are those of the OHADA accounting reference \\
& framework, which was drafted about 15 years ago. \\
& They need to be reviewed significantly to align \\
& them to IFRS. A number of initiatives have already \\
& been taken in this regards by CNC OHADA, with \\
& assistance from the World Bank. Accounting \\
& standards for public interest entities are expected to \\
be made compliant to IFRS within a period of three & years. Training programmes and guidelines will be \\
designed to enable professionals to master the new \\
standards.
\end{tabular}

The analysis shows that in order to make any progress towards meeting the requirements of the SMOs, there is a need for a professional association with the appropriate technical, institutional, and financial capacity. In addition, the national accounting standards commission should function adequately.

20. CEMAC texts provide for the establishment of a code of ethics which has however not yet been drafted. CEMAC is expected to adopt the most recent translation of the IESBA Code of ethics in order to ensure that all accounting professionals within the region uphold the highest quality of ethical standards. The most recent version of the code of ethics (effective from $1^{\text {st }}$ January 2011), was translated by a group of Francophone IFAC members, in line with this organisation's translation policy. In this area, it may be necessary to ensure that CEMAC has the necessary technical capacity to put in place a mechanism to regularly review and adopt the French translations of IESBA standards. Such mechanisms should have national counterparts, as part of the activities of national associations, to enable them transpose these standards and assist their members in implementing them through continuing professional training and the drafting of implementation guidelines.

21. Article 45 of regulation $n^{\circ}$ 11/01-UREC-027-CM-07 of 5 December 2001, revising the status of independent accounting professionals, obliges all public accountants licensed by CEMAC, whether they are individuals or corporate bodies, to take out an insurance policy. This policy covers any liabilities that they may incur as a result of their work. In practice, in Chad, the mission noted that only three (3) firms are in compliance with this provision.

\section{Education and professional training}

22. The smooth functioning of the higher education system in Chad has for a long time been plagued by political crises and repeated strikes. However, recently it has also been affected by the exponential growth in the number of students. The number of students in higher education in Chad increased by 76 percent between 2012 and 2013, going from 17000 students to 30000 students. This increase can be explained by population growth, the age structure within the population, and the increased school enrolment rate. In spite of efforts undertaken by the authorities to construct additional 
public educational infrastructure, which led to the opening of secondary universities in the country's major cities, the Chadian educational system is nevertheless finding it difficult to absorb the numbers of students graduating from high school ${ }^{22}$. This is one of the reasons why several private schools have been established, particularly in Ndjamena (about 44 in accounting and management). All these schools do not however use a harmonised curriculum and sometimes the course content varies even within the same school or university. As a result, the quality of accounting and auditing education is rather poor, especially with regard to subjects taught, numbers of teaching hours, and human resources. The authorities had therefore initiated a programme to evaluate schools, but only one out of the three planned assessments has been carried out. Furthermore, although a national meeting on education was held in 2012, it appears that the difficulties of the higher education sector were not sufficiently dealt with during this meeting. In the public higher education sector, the main management training centre is at the faculty of management and economic sciences of the University of Ndjamena where candidates are selected based on applications received, and which trains accounting and finance professionals. There are currently about 900 students studying economic sciences and management in this faculty. Although the Degree, Masters and Doctorate (LMD) system was adopted in 2008, the faculty does not yet teach Masters' courses. The largest private school providing training in accounting and management professions is HEC Chad. The school was established in 2004 and has grown significantly ${ }^{23}$. From the start, it built a partnership with the management faculty of the University of Ndjamena. Out of the 170 national BTS exam candidates, about 100 were from this school.

23. Like other CEMAC member countries, Chad does not have a public accountancy training programme. However, some attempts have been made to develop such a programme within the regional community in the past. Candidates who wish to become CEMAC accredited public accountants must be holders of a public accountancy diploma certification, or an advanced diploma in accountancy that is recognised by competent authorities ${ }^{24}$. There is however no curriculum leading to a public accountancy diploma in any of the CEMAC member countries. From the time of the UDEAC, advanced accountancy examinations in the zone have been organised by member states with support from CEMAC, in accordance with Act $\mathrm{N}^{\circ}$ 6/73-UDEAC-161 of 22 December 1973, adopted by the Council of Heads of State. This Act also outlines the reform programme for the advanced accountancy examinations. This text was amended by Act $\mathrm{N}^{\circ}$ 4/89-UDEAC-161 of 13 December 1989 , adopting the texts governing the reorganisation of advanced accountancy exams and their methods of application. They also provide for a curriculum leading to a CEMAC public accountancy diploma certification.

\footnotetext{
${ }^{22}$ There are 9000 students in the University of Ndjamena, 4000 in Abeche, 3000 in Moundou, etc.

${ }^{23}$ The numbers have increased from the initial 354 to 1700 today

${ }^{24}$ In reality, only the French Diplôme d'expertise comptable is recognized
} 


\section{Box n¹ - Stages of the CEMAC Public Accountancy Diploma (Diplôme d'expertise comptable)}

Aptitude Test and Assessment Exam, whose objective is to assess the candidate's aptitude for the advanced accountancy training programme. The candidate must hold a CAP in accountancy or an equivalent qualification. Successful candidates are given a certificate on passing the aptitude test which allows them to sit the assessment exam for the advanced accountancy diploma (DECS) for the same session.

The DECS assessment exam enables candidates to prepare for DECS certificates, namely, the accountancy studies certificate, the legal studies certificate, and the economic studies certificate. Successful candidates are given an attestation of success that allows them to register for the DECS courses.

The advanced accountancy diploma (Diplôme d'Etudes Comptables Supérieures - DECS) paves the way for preparing the Public Accountancy Diploma (Diplôme d'Expertise Comptable - DEC). The objective is to assess the technical knowledge that constitutes advanced accountancy training. It comprises three certificates: the accountancy studies certificate, the legal studies certificate, and the economic studies certificate

The Public Accountancy Diploma is awarded to candidates who have undergone the highest level of accountancy training which comprises 2 certificates: the advanced accounting and auditing certificate, and the advanced certificate in organisation, management, and management information systems. After obtaining these certificates, the candidate is required to undergo a 3 year internship in a chartered accountancy firm, once they have presented their dissertation.

In 1989, the UDEAC General Secretariat was given the mandate to establish a regional advanced accountancy school, the Ecole Communautaire de Formation Comptable Supérieure (ECFCS). It was asked to carry out a feasibility study, and had the option of recruiting one or two consultants. Only one person responded to the call for tenders launched in 1996, and again in February 1997. In July 1997, the UDEAC steering committee instructed the UDEAC General Secretariat to begin negotiations with the Catholic University of Yaounde, which had demonstrated its experience in this area. On 2 October 1997, the authorities of the university submitted their proposals to carry out the feasibility study for the creation of the school to the UDEAC GS. Although a mission was carried out in the University of Yaoundé to review the possibilities of cooperation between the latter and the UDEAC Secretariat, nothing ever came out of those discussions, and to date not a single exam session has been organised. The CEMAC could rely on the DECOFI system in the WAEMU countries which is currently being harmonised with the LMD system.

24. In partnership with the Paris-based national institute of economic and accounting techniques (INTEC), a firm operating in Cameroon attempted to set up a French public accountancy training programme. Through this initiative, INTEC training sessions and exams were held in Chad. Unfortunately due to the relatively high costs (about FCFA 600000 or USD 1200 for each credit unit) and the low success rates in the exams, the course was not very popular. In practice, however, the INTEC course remains the best option available in order to successfully complete the French public accountancy diploma certification.

25. The CEMAC regional texts do not regulate the post-qualification continued professional training. There are no national or sub-regional regulations governing continued professional training. In practice, each firm organises continued training for its staff. Professionals who do not belong to major international networks thus do not have the means to pay for the high cost of training. ANECAT should seek to organise some activities for the benefit of its members, as it has done in the past, with assistance from the World Bank. Continuing professional training is considered absolutely necessary if accounting professionals are to maintain the requisite levels of technical and professional competence to enable them provide quality of services and for auditors to carry out their audit function effectively. As mentioned above, it is particularly important to develop continued training 
programmes that are regularly updated into take account changes in accounting and auditing standards and ethics. This will also ensure that accounting professionals have sound knowledge and understanding of the standards they are supposed to apply. Furthermore, the international education standard, IES 7 Continuing Professional Development, requires that mechanisms be put in place to ensure that professional accountants do participate in such courses and comply with the requirements of continuing professional training. This is however not the case in Chad.

\section{Accountancy standardisation in Chad}

26. By belonging to both CEMAC and OHADA, it means that Chad has three levels of standard setting. It is important to note member countries are required to adhere to the directives and regulations agreed upon at the regional level and hence have a heavy bearing on the establishment of national rules and regulations:

\begin{tabular}{|c|c|c|c|}
\hline Sector & National & & Regional \\
\hline & & CEMAC & OHADA \\
\hline $\begin{array}{l}\text { Accounting } \\
\text { commercial, standardisation for } \\
\text { enterprises }\end{array}$ & $\begin{array}{l}\text { An OHADA standardisation } \\
\text { commission was set up in the country } \\
\text { by Ministry of Justice decree } \mathrm{N}^{\circ} \\
\text { 0018/PR/PM/MJ/SG/2011 of } 21 \\
\text { September } 2011\end{array}$ & $\begin{array}{l}\text { CEMAC } \\
\text { Executive } \\
\text { Secretariat in } \\
\text { liaison with } \\
\text { the OHADA } \\
\text { Permanent } \\
\text { Secretariat }\end{array}$ & $\begin{array}{l}\text { OHADA accountancy } \\
\text { standards commission }\end{array}$ \\
\hline $\begin{array}{l}\text { Accounting standardisation for } \\
\text { banks and micro-finance } \\
\text { institutions }\end{array}$ & $\begin{array}{l}\text { COBAC regulations are directly } \\
\text { enforceable nationally }\end{array}$ & COBAC & Not applicable \\
\hline $\begin{array}{l}\text { Accounting standardisation for } \\
\text { insurance companies }\end{array}$ & $\begin{array}{l}\text { CIMA regulations are directly } \\
\text { enforceable nationally }\end{array}$ & $\begin{array}{l}\text { CEMAC } \\
\text { Executive } \\
\text { Secretariat in } \\
\text { conjunction } \\
\text { with CIMA }\end{array}$ & Not applicable \\
\hline $\begin{array}{l}\text { Accounting standardisation for the } \\
\text { accountancy profession }\end{array}$ & $\begin{array}{l}\text { Lack of any national texts on } \\
\text { standards for the accountancy } \\
\text { profession }\end{array}$ & $\begin{array}{l}\text { CEMAC } \\
\text { Executive } \\
\text { Secretariat }\end{array}$ & $\begin{array}{l}\text { There is no } \\
\text { accountancy standards } \\
\text { body in the OHADA } \\
\text { region }\end{array}$ \\
\hline
\end{tabular}

27. Chad has established a national accountancy standards commission. The regulation instituting the accountancy standards commission (CNC OHADA) in the OHADA Permanent Secretariat was adopted by the Council of Ministers, during its meeting held in December 2008 in Dakar. Article 3 of that regulation stipulates that "the CNC OHADA is an advisory body which may make proposals regarding accountancy standards with the aim of assisting OHADA in interpreting, harmonising, and updating accountancy standards within member States. The commission shall coordinate and collate theoretical and methodological research on standards and the enforcement of accounting rules. Upon the request of the Permanent Secretariat, CNC OHADA may also draft reforms on accounting rules and regulations". At the national level, Chad has since 2011 established a national accountancy standard commission in charge of transposing the standards adopted by CNC OHADA into domestic legislation. The Chadian CNC was established by Ministry of Justice decree $\mathrm{N}^{\circ} 0018 / \mathrm{PR} / \mathrm{PM} / \mathrm{MJ} / \mathrm{SG} / 2011$ of 24 September 2011. It is made up of 17 members as well as 17 alternate members. The CNC is however not yet fully operational in Chad and therefore cannot play its role in making proposals for the proper enforcement and updating of the OHADA accounting system. 
28. In the area of standards and regulation of the profession, article 6 of Regulation $n^{\circ} 11 / 01$ UREC-027-CM-07 of 5 December 2001, revising the status of independent accounting professionals calls on CEMAC to set up a higher council of national professional associations (Conseil Supérieur des Ordres Nationaux - CSON). Under the terms of this article, the council shall be a legal entity established by the national associations of chartered accountants of CEMAC member states. It shall work closely with the CEMAC Executive Secretariat to provide the necessary expertise in the regulation and promotion of the accountancy profession. To this end: (i) it shall constantly analyse existing professional doctrine, ethics and standards and make recommendations for the enforcement of such texts; (ii) it shall help the CEMAC Executive Secretariat and member states putting in place accountancy training centres, and (iii) shall supervise the establishment and functioning of quality control within the CEMAC region. Due to the fact that CEMAC member states do not yet all have professional bodies in place, the CEMAC region standardisation and supervision body has not yet been established. Out of the six CEMAC member countries, only two (2), Cameroon and the Central African Republic, have a national association of chartered accountants. The four other member states of CEMAC do not have such an association in place.

29. An accountancy standardisation and oversight body, the CNSPC, is also planned in the OHADA region. A draft regulation was discussed during a meeting held in Lome, Togo in December 2010, which was organized by the permanent Secretariat. During this meeting, a draft regulation establishing, organising, and describing the functions of the Commission de Normalisation et de Supervision de la Profession Comptable (CNSPC) des Etats parties de l'OHADA was discussed. At the time of this ROSC mission, the draft regulation had not yet been adopted by the Council of Ministers. This commission will be in charge of (i) ensuring the establishment of a professional association of chartered accountants in all member States; (ii) drafting organic texts governing the accountancy profession; (iii) defining the training programme and curriculum for the public accountancy diploma and contributing to the design of accountancy training programmes in States parties; (iv) setting the minimum duration and content of continuing professional training programmes for professional accountants; (v) drafting professional standards, and (vi) defining the service quality control process to be applied by sub regional bodies and/or national associations in member countries.

30. Where accounting and auditing standards are concerned, the overlap between CEMACCNC OHADA and CEMAC-CNSPC (when set up) should be noted. CEMAC regulation $\mathrm{N}^{\circ}$ 5/99/CEMAC-002-CM-02 of 17 August 1999, describing the organisation and functioning of the CEMAC Executive Secretariat established a department in charge of accountancy standards within Executive Secretariat. Article 47 of the regulation stipulates that this department is in charge of setting standards, as well as harmonising and modernising the accountancy profession. In the case of WAEMU, it sets standards and regulates the accountancy profession within region. OHADA, which was created more recently, plays the same role, as it federates both the WAEMU and CEMAC regions. It is therefore clear that coordination mechanisms need to be put in place in order to enhance existing synergies and prevent the risk of duplication of activities among the three organisations. This could in particular be the case in the area of establishing a continuous process of upgrading the OHADA accounting system and moving towards adopting and implementing IFRS, and promoting the enforcement of professional standards. With the planned establishment of the CNSPC in the OHADA region, two accounting standards and regulatory bodies would coexist in the CEMAC region. Standards set by CNSPC would be applicable to the 16 OHADA member States, while those set by Council of National Associations (CSON) would be applicable to the six CEMAC countries, without coordination mechanism being put in place to monitor on-going research and other activities. Since the latter organisation has not yet been established, due to the absence of national associations of chartered accountants in all CEMAC member states, it would be more reasonable to avoid duplication by amending the CEMAC texts. Such an amendment could recognise the CNSPC (OHADA) as the only standard-setting and oversight body for the profession within the CEMAC zone. To this end, there is a need for enhanced coordination among CEMAC, WAEMU, and OHADA. 
31. Standards for credit institutions are set by the Central African banking commission (COBAC) under the terms of article 32 of the agreement ${ }^{25}$ on banking activities and oversight. The banking law, which entered into force on 1 January 1999, makes it mandatory for banks and financial establishments to prepare their accounts in line with the accounting provisions and rules decided by the commission. According to the regulation, the commission as the accountancy standards oversight body sets the framework within which accounting standards for the banking sector are enforced. The commission is also the standard-setting body for micro-finance institutions, which use a specific accounting plan. Part III of this report on accounting standards, reviews the enforcement of the banking chart of accounts with reference the IFRS framework. It is noteworthy to state that the World Bank is currently financing a project to support financial institutions in defining an accounting framework that is harmonised with Basle II. COBAC, CEMAC, and OHADA are members of the project steering committee and are thus expected to prepare recommendations on the establishment of a new accounting framework for financial institutions.

32. The standards regulatory body for the insurance sector is CIMA. It is a member of the OHADA accounting standards commission and it intends to review the rules governing accounting for insurance companies within the framework of CNC OHADA: CIMA is a member of CNC OHADA and is therefore expected to review accounting rules within the framework of the commission's ongoing work. However, the CRCA authorities indicated that although the existing CIMA framework has been in place for quite a while, many businesses in the sector are still not very familiar with the chart of accounts due to lack of adequate training, and the appropriate implementation guidelines. The development of accounting rules towards convergence with IFRS, has to take into account the major shortcomings which have been noted in enforcing the existing accounting principles under the CIMA code. Strong support through training programmes needs to be provided.

\section{E. Oversight mechanisms for Accounting and Auditing standards}

33. The entityin charge of regulating the appointment of auditors for commercial companies has not yet been set up. Due to an inadequate legal framework, there are no institutions in place to oversee and regulate the appointment of auditors when companies are established and published in the legal notice journals. There are no provisions for sanctions against business managements who do not have their accounts certified by an auditor. The establishment of a national association of chartered accountants would make it possible to improve the regulation of the appointment of auditors, in accordance with the new regulatory principles. In examining some financial statements, the mission noted that auditors of commercial companies are not always CEMAC-accredited chartered accountants.

34. Where the financial sector is concerned, COBAC has been charged with the responsibility for overseeing the enforcement of the accounting standards including compliance with the chart of accounts for credit institutions (PCEC). The commission has an oversight role over banks and financial institutions. The national monetary authorities are simply informed of the launch of an investigation and of its outcome. COBAC has sole responsibility for carrying out its missions. When an investigation has been initiated, auditors and all other public and private bodies have an obligation to respond to requests from the missions and may not cite professional secrecy as a reason to fail to do so. On average, a bank is audited at least once every two years. The banking commission's inspections cover various aspects: (1) accounting (PCEC); (2) governance, through the reports of both internal and external auditors (opinions on accounts and recommendations on internal control), and (3) regulatory aspects and compliance with prudential rules and standards, particularly COBAC regulations R98/03 and R2003/05 on provisions for loans. The prudential rules in place within COBAC were drafted on

\footnotetext{
${ }^{25}$ The 17/01/1992 convention on the harmonisation of banking regulations in Central African States 
the basis of the principles set out by the Basel Committee on Banking Supervision and also taking into account the economic specificity of the region. The banking commission has extensive sanction powers, and its decisions are immediately enforceable throughout the country of each CEMAC member State. Micro-finance institutions whose balance sheet exceeds 500 million must have their accounts audited by a CEMAC-accredited chartered accountant. In Chad, only one micro-finance network is audited by a chartered accountant. There is a lack of human (6 officials) and financial resources of the Ministry of Finance unit that supervises MFIs.

35. The accounts of insurance companies are audited by the CRCA in the CIMA region, and by the national insurance department at national level. The CRCA has similar oversight and sanction powers to those of the banking commission. Once the CRCA has drafted its report after on-site inspection, insurance companies are given the opportunity to formulate a response to the auditors' observations. These are then communicated to the relevant Ministry, the board of the company, and to the auditors. The frequency of such inspections is about one every two years on average. Each CRCA auditor handles as many as 13 insurance companies, an indication of the inadequacy of the human resources capacity of this institution. Within the Ministry of Finance, there are 6 auditors in the Department dealing with insurance companies. However, very few controls missions carried out.

36. COSUMAF ${ }^{26}$ is charged with the responsibility of ensuring that companies that make public offerings comply with their financial reporting obligations. This institution was established by the conference of CEMAC heads of State on 08 December 2001 and is in charge of ensuring compliance with the obligations related to issuing securities on the financial market. Issuing public offerings refers to individuals or entities whose shares are held by at least 100 persons (not having any legal links) and those that advertise to sell their securities. COSUMAF does not have a specific unit in charge of verifying accounts and financial reporting on the market. In addition, there is a plan to set up a pre-listing compartment similar to WAEMU's BVRM for SMEs and where conditions would more flexible. The first listing of a company only took place very recently and hence none of the financial reporting obligations have so far been enforced COSUMAF.

37. In the absence of a national association of chartered accountants, there is no quality control on the profession as per the international quality assurance standards. Community texts do provide for the establishment of quality control in the CEMAC region, under the supervision of the higher council of national professional associations (article 62 of Regulation $\mathrm{n}^{\circ}$ 11/01-UREC-027CM-07 of 5 December 2001, which revises the status of independent accounting professionals). The higher council of national professional association does not exist at the moment. The commission that was to carry out quality control during the transitional period, under the terms of article 63 has not been established either ${ }^{27}$. However, it is important to note that articles 24 and 25 of the same regulation provide for sanctions for professional misconduct by accountants and auditors. To date, due to the inexistence of the national association of chartered accountants, no quality control standards have been adopted to enhance the quality of audits carried out in the country. Audit firms have therefore been unable to implement any quality assurance standards. Similarly, Chad has no system of external quality control review, which would verify that the activities of audit firms are in compliance with quality standards and other professional standards. In the medium to long term, it would be necessary to put in place a quality assurance system, in line with the IFAC IAASB's International standard on quality control (ISQC 1) in order to ensure quality of accounting and auditing practice in Chad and also to ensure that the code of ethics is complied with within the profession. To this end, a number of guidelines and tools would need to be developed and made available to professional members in order to assist them in implementing internal quality control within their respective firms.

\footnotetext{
${ }^{26}$ Cf. the ff texts: Supplementary act $\mathrm{n}^{\circ}$ 03/01 - CEMAC - CE - Establishing the African financial markets surveillance commission; Regulation $n^{\circ}$ 06/03-CEMAC-UMAC of 12 November 2003 on the organisation, functioning and surveillance of the Central African financial market

${ }^{27}$ This commission was supposed to be in charge of establishing the conditions for external quality control and to have oversight of professional bodies in the CEMAC zone.
} 
Once the professional association is established, investigation and discipline mechanisms should be established as required by IFAC SMO 6, in order to ensure that its members comply with ethical standards (and professional standards) in carrying out their professional activities.

\section{ACCOUNTING STANDARDS}

\section{A. OHADA Accounting System and other Accounting Principles applicable in Chad - Key differences with IFRS}

38. The various chart of accounts applicable in Chad (OHADA Accounting System for entities other than banks and insurance companies, credit Institutions and financial institutions, as well as the chart of accounts under the CIMA Code for insurance companies) differ significantly from the IFRS chart of accounts. Since a comparison of OHADA accounting standards and the IFRS has already been carried out ${ }^{28}$, this ROSC mission in Chad does not cover this comparison exercise. It is noteworthy to recall that the main differences lie in the architecture, conceptual framework, presentation of financial statements and specific recognition and measurement rules.

39. Although it differs significantly from the IFRS, the OHADA Accounting System holds positive features for countries in the region, as well as some advantages that should be unchanged during the harmonisation exercise. Some salient features of the OHADA Accounting System that should remain unchanged include: (1) the three levels of requirements for the three categories of companies (the normal system, the streamline system, and the minimum cash flow system) for financial reporting purposes, should be taken into consideration. However, the definition of the three categories, related to accounting thresholds, and concessions to be provided for small- and medium-sized enterprises (SMEs) are not yet specified; (2) the rules for keeping and organising accounts is another asset of the OHADA Accounting System. However, maintaining these strong points should not counter the adoption of the IASB's international standards without any additions or amendments. The stakeholders interviewed also expressed the wish that any changes in accounting standards should take the economic environment of the country into account. In this regard, it would be appropriate to opt for a gradual harmonisation with IFRS principles without modification. However, as mentioned above, there may still be a need to adopt specific standards for some categories of entities. It would therefore be appropriate to adopt the IFRS for public entities and the revised OHADA accounting standards for SMEs, which would also enable more effective comparison of financial data internationally.

40. The accounting principles applicable to banks and lending institutions contained in the COBAC's Chart of Accounts (PCEC) differ significantly from the IFRS in several respects. As regards the overall presentation of financial statements, it should be noted that the PCEC financial statements contain neither the cash flow statement nor the statement of change in equity. Also the "off-balance sheet" is a completely separate financial statement, due to its sensitive nature and the high volume of off-balance sheet transactions recorded in the banking sector (securities, guarantees, sureties, etc.). From the discussions we had with some senior bank officials from subsidiaries of multinational groups, it would appear that to prepare their group reports, they are obliged to adapt their PCEC accounting system to IFRS requirements. Considering the international environment and developments in international accounting standards, the banking sector cannot refrain from adopting the IFRS. Since a comparison of PCEC accounting standards and the IFRS has already been carried out $^{29}$, the Chad ROSC decided not to replicate this study, and to summarise the key conclusions

\footnotetext{
${ }^{28}$ See ROSC reports on Benin, Côte d'Ivoire, and Senegal, available on the following site http://www.worldbank.org/ifa/rosc aa.html

${ }^{29}$ See Congo and Gabon ROSC reports With respect to the similarities with the UEAMOA PCB, reference may be made to the ROSC reports on Benin, Côte d'Ivoire, and Senegal, available on the following site http://www.worldbank.org/ifa/rosc aa.html
} 
focusing on the architecture, conceptual framework, presentation of financial statements and the specific recognition and measurement rules for assets and liabilities.

41. In the insurance sector, the CIMA Code accounting principles differ sharply from those of the IFRS in several key areas. The CIMA chart of accounts designed for 14 countries has not been amended to comply with the IFRS. Since CIMA is a member of the OHADA standards commission, the CIMA Code could be re-engineered as part of the OHADA convergence exercise. In the opinion of users, this chart of accounts is outdated. Accountants working in insurance companies are trained in the "OHADA Accounting System" environment or on other standards, but in discharging their duties, they use an inappropriate chart of accounts. Moreover, as regards accounting principles, the CIMA Code is based on historical cost, whereas in certain transactions, particularly the assignment of securities or companies, it is inappropriate to use the historical cost. Some professionals in the sector believe financial statements should have been prepared based on the fair value principle, which would be more appropriate for insurance companies. The other major dissimilarities between the CIMA Code and IFRS include no provision for cash flow statement and statement of changes in equity, lower level of reporting required in appendix, etc. The accounting rules applicable to insurance companies, as set out in the Law on insurance also differs from IFRS principles, especially on the measurement of regulated provisions and particularly on (i) provisions for future risks, (ii) provisions for subsequent management costs or equalisation, and (iii) provisions for unearned premiums. Consequently, the insurance sector should work towards adopting IFRS.

\section{B. Review of sample financial statements}

42. On the basis of the financial statements obtained from the Directorate-General for Taxation by the ROSC team, an assessment of the OHADA System implementation level in the country was conducted. The assessment revealed that the OHADA accounting standards were not sufficiently applied by Chadian companies and that the level of financial information was inadequate for international investors. The sample consisted of companies in the trading, transit, oil, building and public works, insurance and banking sectors. The key findings following the review are summarized as follows:

- Financial statements are not always submitted using the CEMAC DSF (annual tax return) format or the OHADA format.

- Accounting rules and methods are almost never adequately set out in the appendix.

- Comments on some key items of the balance sheet are missing from the appendix. These include items such as provision for liabilities and charges for mining companies and trading company stocks, provisions for bad debts for banks, etc. Consequently, the principles of relevance and materiality contained in SYSCOHADA (OHADA accounting system) are not adequately implemented. This leaves the external reader with no relevant financial information whatsoever for a sound understanding of the company's financial statements.

- The OHADA format for financial statements presentation is used for an insurance company, whereas the applicable accounting standards were those for insurance companies. Moreover, the company indicated that the 2 balance sheets ( 1 for the Insurance Department and the other for the DGID using the SYSCOHADA format) were prepared using a bridge table. The mission noted that some of the figures provided were different from those obtained from the Insurance Department.

- Some of the balance sheets prepared using the normal system do not contain any statement of sources and application of funds (TAFIRE).

- Provisions for retirement benefits are not yet properly controlled and accounted for.

- The appendix contains the statements provided for by OHADA and those required by the CEMAC DSF. As a result, it comprises over 30 statements that are likely to be irrelevant to an external reader of financial statements. 
The review indicates that further training is necessary to enable practising accountants as well as accountants in companies to properly implement accounting standards. This may be achieved by improving courses on accounting standards in initial training and continued training programmes. This will also involve updating courses frequently, given that international standards are developed continuously by the International Accounting Standards Board (IASB). In addition to these training activities, guidelines for implementation in the OHADA region could be drafted to help professionals implement these standards.

\section{AUDITING STANDARDS}

43. There are no clearly defined auditing standards applicable in Chad. In the absence of a national association of chartered accountants, the accounting and auditing framework is still incomplete and auditing standards are not yet adopted. The accounting profession is thus not subject to the international auditing standards issued by the IFAC IAASB. Furthermore, the Joint SubRegional Committee ${ }^{30}$ established by CEMAC Decision $\mathrm{N}^{\circ}$ 30/01-UEAC-027-CM-07 of 5 September, 2001 setting out the terms and conditions for practicing as chartered accountants is not yet operational. Consequently, accounting firms all apply international standards in a disparate manner. Audit firms that are part of large networks generally apply their group auditing standards, while other individual audit firms struggle to implement the international standards. In reviewing the financial statements, the ROSC mission noted that international standards were not properly understood and implemented. For instance, from some of the audit reports examined the responsibilities of the auditor and those of company directors are not distinguished. Also, there are often confusions between the missions of the statutory auditor with those of the independent auditor.

44. With the exception of subsidiaries of international groups, the OECD corporate governance principles are not applied in Chad, especially those that related to the establishment of audit committees. Generally, the OECD's corporate governance principles are not implemented in the country. The setting up of audit committees in companies of a certain size may help to enhance the quality of financial reporting and facilitate the mission of the statutory auditors. Audit committees play an important role in supervising and monitoring companies' accounting and financial reporting. The audit committee ${ }^{31}$, within of the Board of Directors, acts under the latter's sole and collective responsibility with the main mission of assisting the Board in dealing with issues regarding the preparation and review of accounting and financial information. Specifically audit committees are in charge of monitoring (i) the preparation process of financial information, (ii) the effectiveness of internal control and risk management systems, and (iii) the statutory auditing of the annual financial statements and consolidated financial statements by the Statutory Auditors, as well as the independence of these Statutory Auditors. In this regard, the mission noted that statutory auditors of public enterprises are not all accredited by CEMAC. Furthermore, financial statements are produced late and the internal control system is often extremely weak.

\section{PERCEPTIONS REGARDING THE QUALITY OF FINANCIAL REPORTING}

45. There is little demand for financial information in Chad and this mainly comes from banks. Some of the major weaknesses that make it difficult to avail financial information upon request in the country include the absence of a central balance sheet office and non-compliance with the requirement to submit financial statements to the court registry. The bank officials interviewed in during the study pointed out that they often give little credence to the financial statements provided by loan applicants. Accounting reports are generally produced to fulfil fiscal requirements. It is also generally acknowledged that companies produce multiple financial statements.

\footnotetext{
${ }^{30}$ This sub-regional joint committee is to be responsible for verifying that auditing and quality standards are indeed applied

${ }^{31}$ With the exception of a few subsidiaries of multinationals, very few businesses in Chad have an audit committee or an internal audit department
} 
46. The OHADA accounting reference frameworks for trading companies, the PCEC for banks and the CIMA Code for insurance companies are still misunderstood and poorly implemented. Although accounting standards for these sectors have been in place for a relatively long time, the general view is that there are still numerous shortcomings on company balance sheets submitted to the tax authorities, on those submitted by banks to COBAC, and by insurance companies to the CRCA. In order to develop the standards in alignment with IFRS, there is a need to support the process with large scale training activities to facilitate their implementation by professional accountants and companies.

47. The accounting profession is relatively well-known in Chad, although stakeholders indicate that it is not very well organized. It is nevertheless represented in the main private sector organisation, namely the Confédération nationale du patronat Tchadien. The establishment of a duly recognised national association of chartered accountants, as required by regional community regulations, would considerably enhance the credibility of the profession. The accountancy profession has a major role to play in enhancing the quality of financial information in the country.

\section{RECOMMENDATIONS}

\section{A. ACCOUNTING STANDARDS}

\section{$\underline{\text { At regional level }}$}

48. Recommendation $\mathrm{N}^{\circ}$ : The OHADA Permanent Secretariat should ensure that the ongoing World Bank funded project on technical and institutional capacity building facilitates the proper functioning of the accounting standardisation body (CNC), to enable it to carry out its missions. The World Bank institutional and technical capacity building grant to the OHADA Permanent Secretariat should make it possible to implement the recommendations of the 2009 organisational audit. The project is aimed at supporting activities at the regional level, which will have an impact on exiting national bodies. With the recruitment of a high level public accountant, the development of the website, and the purchase of equipment, its interventions will be significantly enhanced. Furthermore, as part of the capacity building, the various bodies should harmonise their interventions in order to avoid duplication and superfluous decision-making processes.

49. Recommendation $N^{\circ} 2$ : The OHADA standardisation commission should take the necessary steps to converge the OHADA accounting system with IFRS. Accounting standards need to be updated constantly not only to improve their effectiveness in practice, but also to deal with operations and situations that may not have been earlier foreseen. The CNC OHADA should gradually upgrade the accounting standards of the OHADA accounting system, to bring them in line with IFRS. As the regional standardisation body, it should carry out an analysis of the accounting system in order to adapt it to the IFRS, taking into account the economic environment of member countries. Public interest entities (listed companies, banks, insurance companies, and state enterprises) should simply adopt the IFRS by passing of a Uniform Act. More specific and appropriate standards may be adopted for SMEs, and other entities, but these should be compatible with international standards and best practice. In addition, it will be necessary to carry out a large scale initial and continued professional training, as well as developing of implementation guidelines to assist professional accountants and the private sector in implementing the standards. The OHADA Permanent Secretariat could undertake the task of disseminating such standards, developing implementation guidelines, and organising professional training.

50. The Central Bank (BEAC) and CIMA authorities, in conjunction with the CNC OHADA, should ensure that sector specific chart of accounts for credit and insurance institutions are in line with IFRS. The scope of application of the OHADA Uniform Act on the organisation and harmonisation of corporate accounting systems does not cover banks, financial institutions, and 
insurance companies. However, the meeting of the Council of Ministers held in Yaounde from 21 to 24 March 2001, gave instructions for the chart of accounts for banks and financial institutions to be harmonised with the general chart of accounts. There is an urgent need for the chart of accounts in the sectors to be brought in line with the OHADA accounting system and with IFRS in the long run. The alignment of the current accounting norms and codes in the banking sector with the IFRS is on-going. This work led by the Central African financial market oversight commission together with the professional association of credit institutions will be completed by 2016 . Where insurance companies are concerned, although CIMA authorities believe that the insurance code is poorly applied due to unfamiliarity, it is necessary to initiate steps to align the code with international standards, which are more appropriate for the insurance sector.

\section{At the national level}

51. Recommendation $\mathrm{N}^{\circ}$ 4: National authorities should ensure that the standardisation commission (CNC OHADA) established in Chad in 2011 in line with regional community regulations becomes fully operational. Based on the relevant regulations, Chad established a national commission in charge of assessing the implementation of the OHADA accounting system and of making proposals to the regional CNC OHADA. This body is also in charge of transposing the commission's decisions at the national level, and ensuring their implementation. The commission is however not functional and its membership needs to be reviewed in order to include more professional accountants. The commission is expected to serve as a link to the Permanent Secretariat in implementing activities decided at regional level. The CNC OHADA in Chad could also establish a committee bringing together representatives of the private sector and the accounting profession in order to organise sessions on accounting and hence ensure a wide dissemination of the SYSCOHADA in the country.

52. Recommendation $N^{\circ}$ 5: Engage the national authorities to ensure progressive adoption of regional directives on public accounting standards for the State budget and in the long run, ensure compliance with IPSAS. Through PAMFIP, steps have already been taken by government to adopt the various CEMAC directives on public financial management. The transformation of the Chamber of accounts into a Court of Accounts is expected to improve public financial management in the country, and in particular ensuring that the government accounts and budget execution reports are prepared in a timely manner. With the implementation of other directives, the country will be moving towards compliance with SMO 5, which relates to IPSAS public accounting standards.

53. Recommendation $N^{\circ}$ 6: Adopt the necessary texts for the establishment of a $\mathrm{CGA}^{32}$ in Chad through public-private partnership. From the meetings with the private sector and professional accountants, it appears that there is a need for such a centre, to assist SMEs. The authorities must assist the private sector and the accountancy profession in setting up the appropriate framework for promoting SMEs and VSEs. Certain tax advantages could be granted to members of such a centre and a mechanism for providing assistance and support in financial and accounting management would also be established.

\section{B. ACCOUNTANCY PROFESSION - PROFESSIONAL STANDARDS}

\section{At the regional level}

54. Recommendation $N^{\circ} 7$ : Adopt international standards on auditing, at the regional level, and ensure that they are implemented by national associations of chartered accountants in order to

\footnotetext{
${ }^{32}$ The objective in setting up CGAs is (i) to provide entrepreneurs with more incentives for ensuring sound management and transparency in accounting, and (ii) to improve the management systems of member companies while promoting a culture of proper accounting and fiscal management
}

Chad - ROSC Accounting and Auditing 
enhance the quality of the audit work done by statutory auditors. Countries like Belgium, Canada, and France have already translated international auditing standards in compliance with the IFAC translation policy. CNC OHADA could review and adopt them at the regional level. CNC OHADA could also use the French version of the IFAC SMP committee's Guide to using international standards on auditing in the audits of small and medium-sized entities. At both regional and subregional levels, it is necessary to put in place regional auditing standards in line with the international standards and to also set up a system of quality control review in the medium-term, in order to ensure the quality of audits. To promote the use of such standards by auditors, a strong programme of initial and continued training should be designed and regularly updated. National associations of chartered accountants could also disseminate the translated guidelines.

55. Recommendation $\mathbf{N}^{\circ} 8$ : Set up a professional quality control system to be implemented in the CEMAC sub-regional, and in the OHADA regional level. In addition to establishing quality control systems within firms, it is also important to put in place a quality control review system, in line with the requirements of IFAC SMO 1. This will make it possible to ensure that auditing firms comply with quality control standards and other professional standards in carrying out their professional activities. Like other regulatory bodies in the WAEMU region, the quality control review system should be developed in conjunction with the CPPC. Given the limited resources and the difficulties involved in establishing such a system of quality review, this recommendation could be implemented gradually, over a period of five years, and could focus on firms that audit financial statements of public interest entities. As a final component of the system, CEMAC and OHADA should adopt the IFAC code of ethics in order to ensure that members of the profession adhere to the highest ethical standards in carrying out their activities. Planning initial and continued training programmes will be necessary to facilitate implementation.

\section{At the national level}

56. Recommendation $\mathbf{N}^{\circ}$ 9: With the support of the Chadian authorities and the World Bank, ANECAT should continue to take the necessary steps to create a formal accountancy biddy as required by regional community regulations. To this end, the planned training activities should be carried out as soon as possible to enable the newly reclassified chartered accountants to strengthen their capacity in order to provide quality services to clients in line with the international requirements. .. Following the reclassification of the 45 accredited accounting technicians in the category of CEMAC chartered accountants, the priority of the ANECAT and the authorities of Chad should be the formal creation of an accountancy body in order to comply with the CEMAC directives and the strengthening of the capacity of the newly reclassified chartered accountants.

57. Recommendation $\mathrm{N}^{\circ} 10$ : Adopt a law establishing the national association of chartered accountants of Chad in line with CEMAC regional provisions. It is still essential to set up the association in order to enhance the credibility of the profession, both nationally and internationally. The Ministry of Finance and Budget should continue to support ANECAT in its efforts to ensure that the draft text is finally adopted. One of the tasks of the national association of chartered accountants would be to develop its activities in line with IFAC statements of member obligations. Its responsibilities also include: (i) adopting and implementing auditing standards, as well as the code of ethics; (ii) adopting and implementing IAESB international standard through initial and continued training programmes; (iii) adopting quality control standards (the external quality control review should be clarified with regional community institutions in order to avoid duplication between the CEMAC joint commission, the CNSPC, and OHADA); (iv) developing investigation and disciplinary mechanisms to ensure that members of the association comply with ethical standards and other professional standards in carrying out their activities, as well as to control the illegal practice of the profession. All these activities should be carried out in compliance with the requirements IFAC SMO 7. The national association should implement a system of governance that is in line with international best practice and should have adequate technical, financial and institutional capacity. In order to further guarantee that members of the association comply with such standards, the draft bill should include provision for the appointment of a government auditor. The draft text could further define the 
requirements for exercising the profession in Chad and require reciprocity with other CEMAC member countries, since a residence certificate is deemed sufficient for citizens of CEMAC countries (article 12). The draft decree also defines the status of public accountants (carrying out accounting and auditing missions) and that of legal expert in accountancy (for forensic accounting reviews - article 9 of the draft decree). This may lead to confusion within the profession. It would be preferable for such forensic accounting reviews to be carried out by public accountants.

58. Recommendation $N^{\circ} 11$ : Encourage national authorities to take the necessary steps to assist the professional accounting body to make progress towards meeting the IFAC Statements of Membership Obligations by drafting and implementing a roadmap. This roadmap could be financed by donors. The establishment of a national professional association is the first step towards approaching the international professional organisations and the prospect of a future application for IFAC membership (medium and long-term); supporting the development of the national accountancy profession, and enhancing the quality of national financial information in the country. The national association of chartered accountants in Chad could also become a member of FRECAC, a federation of central African associations of chartered accountants.

59. Recommendation $N^{\circ} 12$ : Establish a system of internal quality control within auditing firms in order to ensure the quality of accounting and auditing practice as well as compliance with professional rules of ethics. The association should adopt the international standards of quality control and assist auditing firms in implementing these standards by organizing training sessions and providing members with implementation guidelines as well as other tools as recommended by IFAC SMO 1. The quality control mechanism should be put in place in phases. The professional association could use the IFAC SMP committee's Guide for quality control in small and medium-sized enterprises. The system of quality control should be coordinated with the quality control review system established in the sub-region by CEMAC and/or OHADA.

60. Recommendation $\mathrm{N}^{\circ}$ 13: Engage with the Chadian authorities in order to transpose CEMAC public financial management directives into national regulations and to strengthen governance of state enterprises by ensuring effective control and the establishment of effective internal control procedures, such as internal audit committees. Governance of state enterprises needs to be improved and therefore state control bodies such as the Court of Accounts should play their role in this area. The missions of the Ministry in charge of restoring public affairs should be reviewed with the aim of rationalising its activities. Through the implementation of PAMFIP activities the National authorities should continue working towards transposing the CEMAC directives on public finance. CEMAC authorities should also move towards greater convergence with IPSAS that govern public financial management. All these activities will contribute to improving governance in the state and para-statal sector.

\section{Training}

\section{At the regional level}

61. Recommendation $\mathrm{N}^{\circ}$ 14: Engage with the OHADA Permanent Secretariat in order to adopt an accounting syllabus that enables qualified accountants to practice throughout the region. The necessary consultations should be carried out with the WAEMU with a view of working on the revised syllabus within a reasonable time. In addition, CEMAC authorities could duplicate/adapt the WAMEU accounting diploma (recognised by the Conseil Africain et Malgache de l'Enseignement Supérieur), taking into account the lessons learned during its development in the region. This could reduce the cost of training for Chadian students and facilitate access to studies in accounting and auditing. CEMAC should also finalise the reclassification process for accredited accountants ${ }^{33}$ before the deadline of December 2013.

\footnotetext{
${ }^{33}$ The process includes a training session, submission of an activity report and/or an interview with the panel. 


\section{At the national level}

62. Recommendation $\mathrm{N}^{\circ} 15$ : Develop a programme for compulsory continuing professional education as well as a refresher programme for all members of the profession. Given the importance of updating professional knowledge and the need to comply with the Statements of Membership Obligations (SMO 2), the national association of chartered accountants should set a minimum number of hours of compulsory continuous training, in line with the IFAC IAESB international education standards (120 hours of training over a period of three years). Furthermore, accounting professional bodies could organise seminars for their members with the support of the World Bank or FIDEF. A permanent system should also be put in place to ensure that members of the organisation comply with the requirements for continuing professional training which will be adopted by the professional accounting bodies. The continuing professional training programme should be updated regularly to enable members of the professional organisation keep abreast with accounting and auditing standards as well as ethical standards, as and when they are adopted.

63. Recommendation $\mathrm{N}^{\circ}$ 16: Organise national meetings on higher education, adopt a national curriculum for management and accountancy schools in order to improve the technical quality of their programs, and also put in place a programme of evaluating these schools. The authorities should continue with the process of reviewing higher education in Chad through the organisation of a series of national meetings. There is also a need to put in place a system to inspect private management schools and for recognition of the qualifications awarded by these schools. The public authorities should enhance the quality of professional accounting education in both secondary schools and institutions of higher learning by focusing on competence when recruiting teachers, and by defining a framework for public-private consultation when design the relevant training programmes. The needs of the national economy as well those of the private sector should be born in mind. Moreover, the authorities should ensure that the content of the accountancy teaching programmes are compatible with international standards (in particular the European LMD system). This would enhance the credibility of qualifications obtained in Chad and ensure that equivalence is easily obtained. Following the introduction of a national BTS, the ministry of higher education and vocational training is working to harmonize the programme (curriculum) of the different schools. To enhance the quality of the accounting and finance education, the contribution of the chartered accountants (e.g. ANECAT) and the strengthening of the teachers' skills are required.

\section{ACCESS TO CORPORATE FINANCIAL REPORTS}

\section{At the regional level}

64. Recommendation $\mathrm{N}^{\circ} 17$ : Continue to work on the conciliation between the Douala stock exchange and the BVMAC in order to have a single financial market within the CEMAC region in the long run, and to strengthen COSUMAF to enable it to better play its role. The existence of two financial markets has weakened the stock market activities in the region. The authorities should take the necessary steps to bring an end to this situation. In addition, the COSUMAF capacity should be strengthened and should also be provided support to facilitate the opening of an SME compartment with a view of increasing the number of listed companies on the stock exchange. Should COSUMAF be able to attract SMEs thanks to more flexible admission criteria, this would make the stock exchange more dynamic, giving rise to improvements in the quality of financial information. The entity also requires capacity strengthening with respect to the technical aspects of financial reporting.

65. Recommendation $\mathbf{N}^{\circ} 18$ : Engage with the OHADA Permanent Secretariat in order to implement activities planned for improving the investment climate under the OHADA Bank funded project. Recent assessments of the accounting and auditing architecture in OHADA member countries have revealed major weaknesses in accounting and auditing standards as well as in the area of initial and continued training. The OHADA investment climate improvement project therefore intends to improve the quality of financial information for companies in the region by: (i) updating the Uniform Act on accounting law, in line with international best practice, and (ii) adopting and 
implementing a Uniform Act on audit standards, code of ethics, quality control, and investigation and disciplinary mechanisms. The project will also build the technical and financial capacity of CNC OHADA and assist in the setting up creation of a national association of chartered accountants in certain countries. Finally, the project will also assist the Permanent Secretariat in drafting a professional training curriculum for the accounting profession in the OHADA region and in organising continued training sessions.

\section{At the national level}

66. Recommendation $N^{\circ}$ 19: Technical and organisational capacity enhancement for the Commercial court with regard to enforcement of businesses' obligation to file financial statements. Improving capacity of the Commercial Court of Ndjamena in monitoring and computerisation of the trade register will facilitate business registration, as well as the submission, consultation and filing of financial statements submitted by companies. The OHADA accounting law requires that all companies file copies of their financial statements with the Registry of the Commercial Court. With assistance from the World Bank, the OHADA Project will strengthen the CCJA by computerising the regional RCCM. The aim of the exercise is to have a computerised link between national trade registers and the regional trade registers and thus enhance access to financial information.

67. Recommendation $\mathrm{N}^{\circ} 20$ : Strengthen the capacity of the Court of Accounts by implementing INTOSAI auditing standards. The capacity to the Court of Accounts should be improved to enable it carry out its missions based on INTOSAI auditing standards. The newly Court of Accounts is not staffed yet. The president of the SAI as well as the keys officials are not appointed yet; therefore the SAI is not able to carry out its missions. The SAI should be properly staffed taking into account those of the Ministry for Restoring public affairs and the missions of the two institutions harmonized.

68. Recommendation $\mathrm{N}^{\circ} 21$ : Formalize the creation of a steering committee that will develop a detailed action plan based on the recommendations of the ROSC Accounting and Auditing mission. It will also coordinate and monitor the implementation of the activities. The committee will be made up of seven members and chaired by a senior official from the Ministry of Finance and Budget. Its tasks will include: (1) drafting a detailed action plan, clearly stating the sequence of key activities to be carried out, the persons responsible for each activity and the implementation timelines, as well as the resources required; and (2) coordinating the planned reforms and monitoring their implementation. 